2015

\title{
Answering Canadian Tax Questions: An Introduction to Tax Law Research
}

Sas Ansari

Follow this and additional works at: http:// digitalcommons.osgoode.yorku.ca/olsrps

Part of the Tax Law Commons

\section{Recommended Citation}

Ansari, Sas, "Answering Canadian Tax Questions: An Introduction to Tax Law Research" (2015). Osgoode Legal Studies Research Paper Series. 128.

http://digitalcommons.osgoode.yorku.ca/olsrps/128 


\title{
Answering Canadian Tax Questions: An Introduction to TaX Law Research ${ }^{\S}$
}

\author{
SAS ANSARI* \\ The hardest thing in the world to understand is the income tax. \\ - Albert Einstein ${ }^{1}$
}

\begin{abstract}
Income taxation is a complicated area of law that requires a researcher to master not only a large volume of complex legislation, but because of its 'accessory-law' nature also requires good knowledge of many other areas of law (both statutes and common law). This paper provides an introduction to tax law research in the Canadian context. It begins by introducing the tax research process in Part 1 before moving on to discuss how to find the law and material with legally enforceable consequences in Part 2. The paper, in part 3, discusses primary sources of tax law, and explains how to read, understand, interpret, and use these sources. Part 4 discussed secondary sources of tax law, focousing on government produced materials, before bringing the entire tax law research process together in Part 5.
\end{abstract}

\section{TABLE OF CONTENTS}

1. INTRODUCTION.

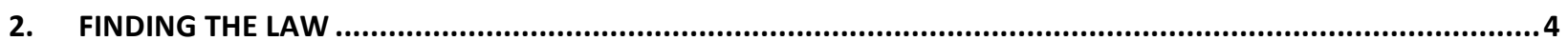

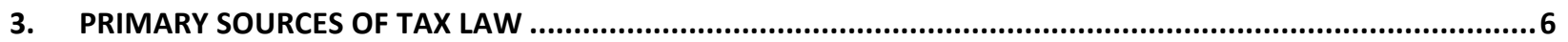

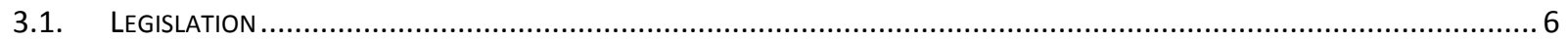

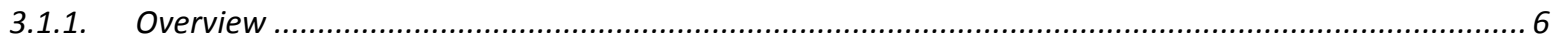

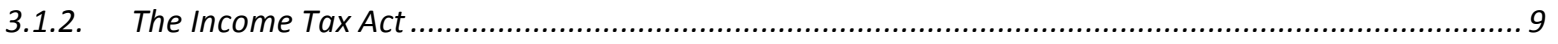

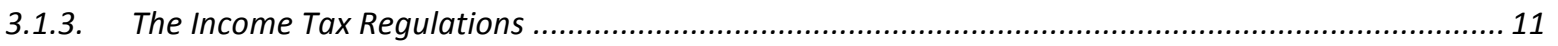

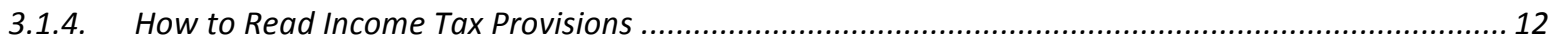

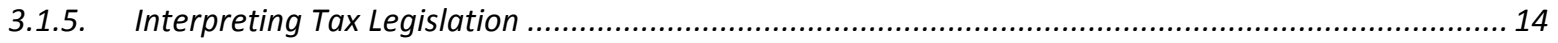

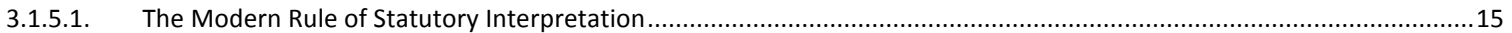

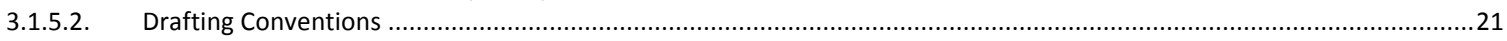

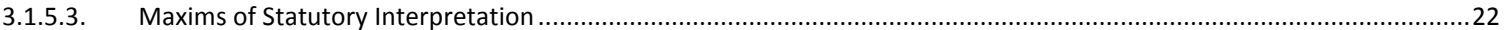

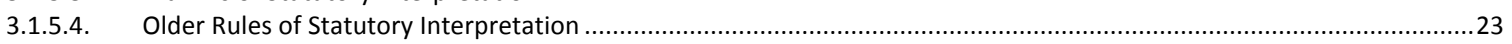

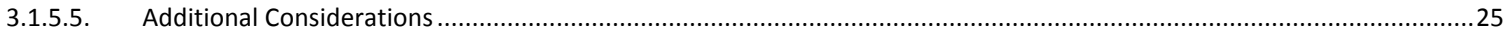

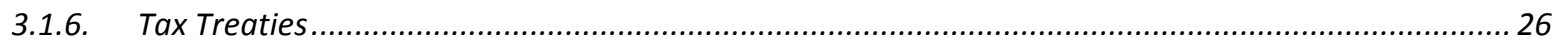

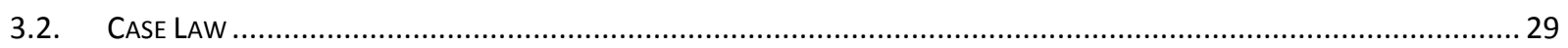

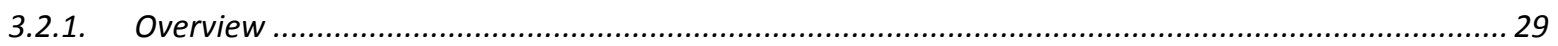

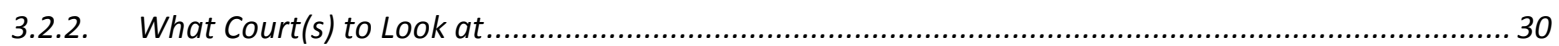

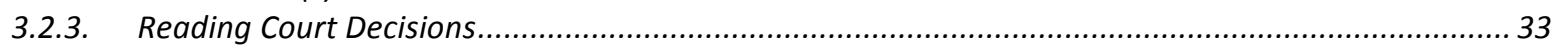

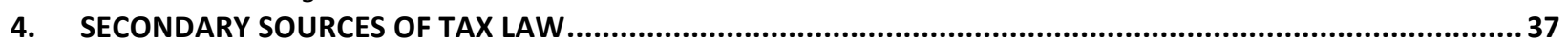

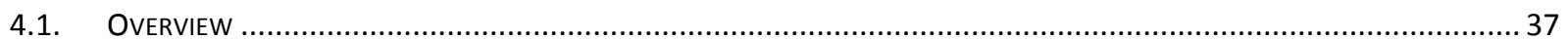

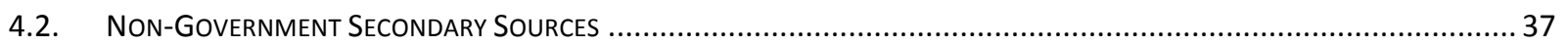

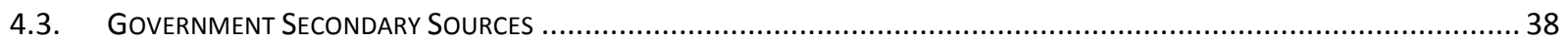

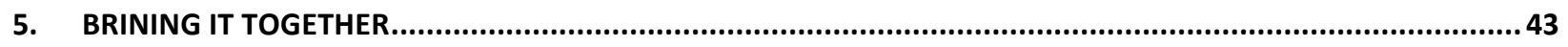

APPENDIX 1 - FUNCTIONAL CLASSIFICATION OF THE ITA .................................................................

${ }^{\S}$ Each of the sections and discussions in this paper could be greatly expanded. This paper should be used as an introduction only and not as an exhaustive guide.

* Sas Ansari is a PhD Candidate (taxation) at Osgoode Hall Law School. Sas holds an LL.M. from Osgoode Hall Law School, York University, as well as J.D. (with Business Law certification), B.Ed., and B.Sc. degrees from the | University of British Columbia. You can view some of his other papers at http://ssrn.com/author=2185221, and view his Canadian tax case comments and summaries at http://ita-annotated.ca/RecentDecisions .

The author would like to thank Justin Kutyan, Neil Brooks, David Sherman, and Saul Templeton for reading and commenting on earlier drafts of this paper.

${ }^{1}$ This quote is attributed to Albert Einstein in a 1963 letter written by Leo Mattersdorf, published in Time magazine. See http:/quoteinvestigator.com/2011/03/07/einstein-income-taxes/. 


\section{Introduction}

Solving legal problems is what lawyers do every day, and solving tax law problems is what tax lawyers do every day. Becoming comfortable and proficient in finding answers to legal problems can be a painful process. The prospect of examining a statute, such as the Income Tax $A c t,{ }^{2}$ so as to find the answer to a question can be intimidating, and the act of reading the statute itself is often arduous. However, knowing how to get answers to particular tax law questions is a basic requirement of tax practice, whether the end goal is tax planning, ${ }^{3}$ tax litigation, ${ }^{4}$ or tax compliance. ${ }^{5}$ In short, it is the a pain that a lawyer will have to endure.

Legal problem solving draws on a general set of skills required for problem solving and clear thinking. However, there are sets of unique skills that apply to the practice of law generally, and approaches that apply to tax practice specifically. Legal problem solving requires that the lawyer distill the relevant facts, identify the legal issues, find the relevant and applicable law, and apply the facts to the law. This simple-seeming process is both cyclical and far from simple. ${ }^{6}$ Every legal problem has a different set of considerations, including: the purpose of the research, ${ }^{7}$ the solution sought, ${ }^{8}$ and the forum/decision-maker/audience where the results will be presented/used. ${ }^{9}$ How research is conducted, what sources are emphasized, and how the results are presented will differ and depend on the specific considerations of each case facing the researcher.

Successful legal problem solving requires one to take a systematic approach. ${ }^{10}$ One step in this systematic approach requires the researcher to identify, locate, and understand the

\footnotetext{
${ }^{2}$ Income Tax Act, RSC 1985 c 1 (5th Supp) (“ITA")

3 "Tax planning" is used here to refer generally to the determination of structural elements of a future transaction or event with the aim of obtaining the most "tax favourable" result possible. With the growth of global interconnectedness of the real and financial economies, there has been growing debate as to what constitutes appropriate versus abusive tax planning. See for example: David G Duff, "Tax Avoidance in the 21st Century" in Australian Business Tax Reform in Retrospect and Prospect, Chris Evans and Rick Krever, Eds (Thomson Reuters, 2009), available online at http://ssrn.com/abstract=1457453. See also Daniel Deak, "International Tax Law and Tax Avoidance: A Case Study on Tax Havens and the Option of Ethics in a Global Economy" in Dal diritto financiario al diritto tributario; Studi in onore A. Amatucci, Volume 5, MA Plazas Vega, Ed, (Temis: Bogotá, 2011) pp 433482, available online at http://ssrn.com/abstract $=2039631$.

4 "Tax litigation" is used here to refer generally to the resolution of tax disputes as between the taxpayer and the tax authority. This includes both administrative review/appeal steps at the Canada Revenue Agency level as well as appeals, actions, or applications to various courts.

5 "Tax compliance" is used here to refer generally to all the procedural requirements needed to demonstrate adherence to the tax laws applicable to the tax filing person. This includes all of the forms, elections, returns, and other materials required by the ITA, Regulations, and Canada Revenue Agency.

${ }^{6}$ The process is cyclical because the search for facts may give rise to new potential legal issues, and the legal research and identification of legal issues may give rise to the need for additional factual inquiry.

${ }^{7}$ There are three general categories that tax research will most often fall into, being research for purposes of: (i) tax planning; (ii) tax litigation; or (iii) tax compliance.

${ }^{8}$ For example: Is the research for purposes of a comfort letter to a client, an opinion letter as part of a business transaction, or in preparation for the fallout of an audit?

${ }^{9}$ The manner of presentation will differ when presenting and drafting, inter alia, a planning memorandum, a legal opinion, a notice of objection, or a factum for the court.

${ }^{10}$ For an overview of a systemic approach to solving legal problems, see Sas Ansari, "Introduction and Overview" (2012) available online at http:/ita-annotated.ca/RecentDecisions/tax-research/introduction-and-overview/ . In brief, there are 6 general steps: (1) obtaining all available and relevant facts and documents; (2) identifying the issues potentially raised by the facts and documents; (3) identifying the law (including interpretation sources)
} 
appropriate law - in other words, conduct legal research. However, before starting legal research, the researcher must first identify the legally relevant facts and the legal issues. ${ }^{11}$ Once this initial background is clarified, the researcher needs to develop a "Research Path": Where to look, in what order, for what information, and to what effect?

The tax issues identified are going to direct the development of the research path. There are five (5) general categories that tax issues can fall into. Identifying what category(-ies) the issue(s) fall(s) into will simplify the research process. The five (5) general categories are: ${ }^{12}$

1) Tax Rules; ${ }^{13}$

a) Procedural;

b) Substantive;

c) Mandatory provisions; or

d) Discretionary provisions;

2) Legal and Interpretation Issues; ${ }^{14}$

3) Calculation Issues; ${ }^{15}$

a) Definition of formulas or description of variables; or

b) Application of formulas;

4) Accounting Issues; ${ }^{16}$ and

5) Factual Issues. ${ }^{17}$

This paper aims to provide the reader with a basic understanding of how to conduct Canadian tax law research, and thereby how to develop and follow through with a research path. It assumes that the researcher has identified the relevant facts and legal issues. The primary focous is on addressing tax issues falling primarily into the category of (1) tax rules, and (2) legal

potentially applicable; (4) analyzing the law; (5) applying the law to the facts; and (6) reaching a conclusion (including an analysis of risks and unknowns).

${ }^{11}$ As indicated before, the relevant facts and legal issues feed back on one another, as does the results of the legal research. These have to be revisited throughout the research process until the researcher is satisfied that all components necessary to pain as full a picture as possible have been identified and obtained.

${ }^{12}$ These five categories, but not the sub-categories, are taken directly from Ted Cook, Canadian Tax Research: A Practical Guide (Carswell: Toronto, 2010) at p 3. As Cook points out, the dividing line between these categories of issues is not clear, and there will likely be overlap amongst the matters that fall into the categories.

${ }^{13}$ Tax Rules are the applicable provisions in statutes and regulations, including those in the Income Tax Act, RSC 1985 c 1 (5th Supp); the Income Tax Application Rules, RSC 1985 c 2 (5th Supp); and Income Tax Regulations, CRC 1978 c 945. For a more detailed listing of relevant legislative sources see http:/itaannotated.ca/RecentDecisions/tax-research/sources-of-information/primary-sources/.

${ }^{14}$ Legal issues are the interpretive issues that come up when trying to ascertain the meaning, scope, and application of the Tax Rules. In order to interpret what the legislation requires, the researcher will need to look at and consider court cases and secondary sources (government documents, textbooks, articles, and so on).

${ }^{15}$ Calculation Issues refers to the formulas that the legislation provides when applying a particular Tax Rule, and the proper application of these formulas using the appropriate variables.

${ }^{16}$ Accounting Issues arise because accounting practice and principles are in the background of tax law and apply unless legislation requires a different approach. The Chartered Professional Accountants (CPA) Canada Handbook is an authoritative guide for Canadian Accounting practice and principles.

${ }^{17}$ Factual Issues are the problems that arise when trying to establish or prove a legally relevant fact. 
and interpretation issues. ${ }^{18}$ In short, this paper aims to allow the tax researcher to find the "law" - the pronouncements that have legal effect when solving tax law problems. ${ }^{19}$

\section{Finding the Law}

Income taxation has grown to be a very complicated area of law. The ITA has ballooned from its eighteen (18) page origins ${ }^{20}$ to legislation and regulations that span several thousand pages. This volume of material alone makes tax research challenging. ${ }^{21}$ In addition to the volume of material, income tax's accessory-law nature (built and dependent on other common law principles and other statutes), ${ }^{22}$ its frequent amendments, ${ }^{23}$ and its purpose of reflecting compromised positions in relation to competing social, economic, monetary, and administrative values/needs complicate this area of law. ${ }^{24}$ Professor Vern Krishna observes that: ${ }^{25}$

[t]he Income Tax Act continues to grow and we fully expect it to double in size and complexity during the next generation. The statute is long - approximately 2100 pages - badly drafted, and written in a style that would make our high school teachers of English cringe with embarrassment. Notwithstanding the complexity of tax law, citizens must endure audits, which, like opera, the revenue authorities conduct in a language that few understand and that usually ends in tragedy.

The role of a tax lawyer is to make the requirements of this opaque text understandable, and so ensure that play does not end in tragedy. A saving grace is that as with any complicated

\footnotetext{
${ }^{18}$ To a smaller extent, the process will also allow the researcher to address (3) calculation issues by identifying the relevant formulas to apply and the manner of identifying the variables, and (5) factual issues by allowing the researcher to determine what types of facts are legally relevant.

${ }^{19}$ Not all pronouncements with legal effect are properly "law" in the positivist sense of the word "law". Some pronouncements have legal effect for all or some taxpayers, in Canada, though they are not legislation, regulations (or other subordinate legislation), or case law. For a great paper discussing some of the issues around the definition of law see Scott J Shapiro, "The "Heart-Dworkin" Debate: A Short Guide for the Preplexed" (2 Feb 2007) University of Michigan Public Law Working Paper No 77, available online at http://ssrn.com/abstract=968657. More generally, see John Finnis, Philosophy of Law: Collected Essays, Volume IVi Oxford University Press: Oxford, 2011) available online at $\mathrm{http} / / / \mathrm{ssrn} . \mathrm{com} / \mathrm{abstract}=1850674$.

${ }^{20}$ Income War Tax Act, 1917, 7-8 George V c 28.

${ }^{21}$ For example, trying to determine whether an estate is a trust, and when it is or is not a trust, is not an easy task. For the solution see Sas Ansari, "Death and Taxes: The Nature of the Deceased's 'Estate', its Relationship to the Deceased, and Practical Implications for Reassessments" available online at http://ssrn.com/abstract=2381553.

${ }^{22}$ For example, Justice Lyons of the TCC recently stated in Al-Hossain v The Queen, 2014 TCC 379, at para 23: It is well established in the jurisprudence that the court must look at the legal relationships that were entered into by private and contract law and tax consequences flow from those relationships.

${ }^{23}$ The ITA is frequently amended for a number of reasons. Tone reasons is that the ITA is a tool for social and economic policy, and need to be revisited to respond to changing social and economic circumstances and demands. Another reason is that there is a constant back-and-forth between taxpayer's who plan to minimize tax and the government that tries to raise revenues through taxation, leading to amendments to close "tax-loopholes" and correct technical oversights and deficiencies.

${ }^{24}$ The ITA contains not only revenue collection measures but also tax expenditure measures that are akin to budgetary expenditure measures that deliver benefits, aid, incentives, and subsidies to those persons or groups meeting relevant criteria.

${ }^{25}$ Vern Krishna, "Preface", in Fundamentals of Canadian Income Tax, 9th Ed (Thomson Carswell: Toronto, ON, 2006).
} 
system, the income tax system is built on foundational concepts and is animated by an inherent logic. ${ }^{26}$ The ITA is structured in a logical manner and the provisions are generally, though not obviously, organized. By understanding these foundational concepts, grasping the animating logic, and deciphering the logic and organization of the ITA the researcher is better able to navigate the maze, and avoid feeling as Justice Learned Hand did when he wrote: ${ }^{27}$

In my own case the words of such an act as the Income Tax ... merely dance before my eyes in a meaningless procession; cross-reference to cross-reference, exception upon exception - couched in abstract terms that offer no handle to seize hold of - leave in my mind only a confused sense of some vitally important, but successfully concealed, purport, which it is my duty to extract, but which is within my power, if at all, only after the most inordinate expenditure of time. I know that these monsters are the result of fabulous industry and ingenuity, plugging up this hole and casting out that net, against all possible evasion; yet at times I cannot help recalling a saying of William James about certain passages of Hegel; that they were no doubt written with a passion of rationality; but that one cannot help wondering whether to the reader they have any significance save that the words are strung together with syntactical correctness.

Legal research is the process of finding cases, legislation, textbooks, articles, and other reference tools that help shine light on a particular legal question. It also requires the researcher to verify that the "law" as found continues to be valid and applicable (has not been overruled, repealed, or significantly questioned or criticized). In trying to determine what the applicable law is, a researcher will look at two general sources: (a) primary sources; and (b) secondary sources. Primary sources are those sources that make up the law proper. Secondary sources are those sources, including government documents and publications, that are potentially helpful in interpreting primary sources and developing arguments on the basis of primary sources. Note that some government publications that are secondary sources, ${ }^{28}$ and therefore not strictly speaking "law", may have legal effect in particular circumstances as determined by principles of Administrative Law. $^{29}$

Generally, legal research begins by looking at secondary sources of law so as to gain a general understanding of the law in a particular area, the regulatory authority's position in relation to that area, the leading cases in that area, as well as related provisions or statutes that

\footnotetext{
${ }^{26}$ For example, understanding the theory and policy behind the definition of "income" will allow a researcher to know what items of receipts may give rise to tax consequences. This paper will not attempt to explain the inherent logic and foundational principles that animate Canada's income tax system. This information is the subject to introductory tax courses, or can be obtained by reading tax textbooks (see for example David Duff, et al, Canadian Income Tax Law, 4th Edition (LexisNexis Canada: Toronto, ON, 2012)). Rather, the paper aims to show the researcher where to look for the law or for items having legal effect.

${ }^{27}$ Learned Hand, "Thomas Walter Swan" (1947) 57 Yale L J 167 at 169.

${ }^{28}$ Some government publications have the force of law. This happens when the legislation authorizes the government agency to produce such materials. For example, the Corrections and Conditional Release Act, SC 1992 c 20, at section 98, authorized the Commissioner of Corrections to issue directives. These directives are similar to internal manuals produced by the CRA, but unlike those materials have the force of law because they are authorized by the statute.

${ }^{29}$ Discussed further below at 4.2 "Government Secondary Sources".
} 
apply to that area. The researcher then turns to the primary sources to form his/her own opinion as to the applicability and effect of the law to the particular circumstances of the client.

Next, Part 3 of the paper will examine the primary sources of Canadian tax law by considering legislative instruments, tax treaties, and the case law, as well as the principles that apply when reading, interpreting, and applying legislation and case law. Then the paper will consider secondary sources of Canadian tax law and the use that can be made of these sources in Part 4, with a particular focus on government documents and publications. Part 5 will bring these elements together and guide the researcher in developing an answer to the legal question.

\section{Primary Sources of Tax Law}

Primary sources are statements of the law itself that are formally/officially recognized as having the force of law within a jurisdiction. It is the courts that ultimately determine what sources and statements have the force of law or have legal effect. ${ }^{30}$ In Canada, legislation (statutes and regulations), treaties that have been ratified and incorporated into Canadian law, and court decisions are primary sources of law. Any interpretation, opinion, or action of a researcher must ultimately rest on these sources.

Tax law is principally statutory, meaning that the starting point and foundation will be legislation. Double Tax Conventions (commonly called tax treaties) are, when ratified and incorporated into Canadian law, ${ }^{31}$ also primary sources on par with legislation. ${ }^{32}$ Case law primarily interprets the legislation and treaties, determining their application to various facts and circumstances. However, the judicial decisions are also important because the common law (judge-made law) also forms part of the legal background against which the ITA operates. ${ }^{33}$

\subsection{Legislation}

\subsubsection{Overview}

The starting point for Canadian income tax law is the Income Tax Act ("ITA"), which imposes the federal income tax. Provincial legislation imposing income taxation generally works from, or builds on, the ITA. ${ }^{34}$ As mentioned earlier, income tax law is a accessory-law or

\footnotetext{
${ }^{30}$ Not all sources and statements that have legal effect are "law". This matter will be addressed in more detail below. The reason a researcher must consider non-law sources that nevertheless have legal effect, is precisely because the outcome of a case is affected by all items that have legal effect.

${ }^{31}$ Because of Canada's federalism structure, the power to negotiate and ratify treaties, including tax treaties, lies with the executive branch of the Federal Government (the Cabinet), but such treaties do not have legal force in Canada until they are incorporated into Canadian law by passing a Bill through the Legislative branch (Parliament).

${ }^{32}$ The ITA

For an overview of Canada's treaty making process see Treaty Practice and Procedure available online at http://www.treaty-accord.gc.ca/procedures.aspx.

${ }^{33}$ For example, the ITA provides an inclusive definition of "income" in section 3, but does not define what the term "income" means. The definition of "income" comes from the common law. Therefore, although the income tax is statutory, it cannot be understood without grasping the legal concepts that create the space within which the statute operates.

${ }^{34}$ Note that the constitutional power to tax is different at the federal level as compared to the provincial level. The Constitution Act, 1867, 30 \& 31 Victoria, c 3 (UK), at subsection 91(3) gives the federal government the power for
} 
gloss on the law - it is something that is applied, unless the law provides otherwise, after all other laws have been applied to the circumstances giving rise to tax consequences. ${ }^{35}$ This means that, depending on the particular facts and circumstances, a researcher may have to look at provincial $^{36}$ and other federal legislation ${ }^{37}$ (as well as the case law interpreting these other pieces of legislation), and sometimes the law of other countries, ${ }^{38}$ so as to get to the right solution. ${ }^{39}$ It is not always easy determining what jurisdictions and what laws a researcher needs to consider. Practice, experience, and diligent use of secondary sources (and seeking the guidance of senior practitioners) will pave a path towards eventual mastery.

"The raising of Money by any Mode of System of Taxation", while subsection 92(2) grants the provinces the power to impose "Direct Taxation within the Province [...]".

Each province and territory has a variety of taxing statutes that impose personal and corporate income taxes, retail sales taxes, property taxes, land transfer taxes, tobacco taxes, fuel taxes, and so on. Sometimes, a term or phrase in the ITA may not have been interpreted or considered in a case dealing with the ITA, however it may have been interpreted in the context of a provincial taxing statute that uses the same word or phrase as the ITA. Although such a decision would not be determinative for purposes of the ITA, the decision would be persuasive.

Note that Quebec and Alberta administer their own income tax and their legislation is not as harmonized with the ITA as the legislation in other Provinces and Territories (though there is a great degree of similarity between those provincial statutes and the ITA).

${ }^{35}$ See for example the SCC decision in Will-Kare Paving \& Contracting Ltd $v$ Canada, [2000] 1 SCR 915, where the court stated that the ITA does not operate in a vacuum, and that legal characterization of the broader commercial relationships and law affect the operation and effect of the ITA. In this case, the word "sale" has an established meaning in law, and its not open to the ITA to broaden that meaning to include the popular meaning of the word.

See also the decision of the Federal Court in Crown Tire Service Ltd. v. The Queen, [1984] 2 F.C. 219 (T.D.), where the common law and the provincial sale of goods laws were used to define the scope and meaning of the ITA provisions dealing with the manufacturing and processing incentives.

${ }^{36}$ Provincial legislation is available online at the various provincial or territorial government websites, or through the Canadian Legal Information Institute (CanLII) at http://canlii.org .

One example where provincial law is important is in the example of Director Liability under the ITA or ETA, where the director must be assessed within 2 years of ceasing to be a director. How and when a director of a corporation ceases to be a director is governed by the provincial corporate law where the particular corporation is provincially incorporated.

${ }^{37}$ Some other potentially relevant federal legislation includes:

- Canada Business Corporations Act, RSC 1985 c C-44;

- Indian Act, RSC 1985 c I-5;

- Bank Act, SC 1991, C 46;

- Bankruptcy and Insolvency Act, RSC 1985, c B-2;

- Foreign Missions and International Organizations Act, SC 1991, c 41;

- Tax Court of Canada Act, RSC 1985 c T-2;

- Pension Act, RSC 1985, c P-6;

- Federal Courts Act, RSC 1985, c F-7;

- $\quad$ Tax Rebate Discounting Act, RSC 1985, c T-3;

- Visiting Forces Act, RSC 1985, c V-2;

- Canada Disability Savings Act, SC 2007, c 35;

- Canada Education Savings Act, SC 2004, c 26;

- Corruption of Foreign Public Officials Act, SC 1998, c 34; and

- Various Budget Implementation Acts.

${ }^{38}$ For example, determining whether a foreign entity 'owned' by a Canadian resident corporation is a partnership or a corporation for Canadian tax purposes, and therefore the treatment of the income of that entity for Canadian tax purposes, depends on the legal character of that entity as determined by the law of the foreign jurisdiction.

${ }^{39}$ For example, to calculate Paid Up Capital of a corporation, a researcher will need to refer to the corporate statute under which the corporation in question has been organized or continued. 
It would be impossible to list all of the other federal and provincial statutes (and regulations) that may be of importance in tax law research. However, there are some that come into play more often than others. These other important pieces federal legislation include: ${ }^{40}$

- Constitution Act, 1867;

- Canadian Charter of Rights and Freedoms; ${ }^{42}$

- Income Tax Regulations ${ }^{43}$

- Income Tax Application Rules; ${ }^{44}$

- Income Tax Conventions Interpretation Act; ${ }^{45}$

- Interpretation Act; ${ }^{46}$ and

- Remission Orders under the Financial Administration Act. ${ }^{47}$

As stated above, general common-law concepts are also imported into the ITA. ${ }^{48}$ Knowledge of other areas of law (including contract law, corporate law, property law, and so forth $)^{49}$ is important so as to understand the meaning and effect of ITA provisions. ${ }^{50}$ The meaning of a word or phrase in tax law may depend on that word's or phrase's meaning in another area of law, or on the judicial interpretation of that word or phrase found in other

${ }^{40}$ To see a listing of, and the full text of, all federal statutes and regulations refers to the Department of Justice LAWS site at http://laws.justice.gc.ca/eng/.

${ }^{41} 30$ \& 31 Victoria, C 3 (UK), sections 53-57, 91(3), and 92(2).

${ }^{42}$ Part I of the Constitution Act, 1982, being Schedule B to the Canada Act 1982 (UK), 1982, c 11.

${ }^{43}$ CRC 1978 c 945 ("ITR"). The regulations provide additional detail that supplements the ITA's more general provisions, or provides for things that the ITA states will be "prescribed".

${ }^{44}$ RSC 1985 c 2 (5th Supp). This legislation was enacted as part of the major income tax reforms undertaken in 1971, and provided transitional rules between the old and the new system. Some of these rules may still be relevant today (for example is a taxpayer continues to own property that they owned prior to 1972).

${ }^{45}$ RSC 1985, c I-4. This legislation provides specific rules that apply to the interpretation and application of Canada's tax treaties, and was introduced in response to the Supreme Court of Canada decision in $R v$ Melford Developments Inc, [1982] 2 SCR 504, available online at http://canlii.ca/t/1z1cw.

${ }^{46}$ RSC 1985, c I-21. This legislation governs the interpretation of all Federal statutes, providing both general rules of interpretation and definitions.

${ }^{47} \mathrm{RSC} 1985$, c F-11.

${ }^{48}$ The Federal Court of Appeal in Dale v. Canada, [1997] 3 FCR 235, at paragraph 13, stated:

In determining whether a legal transaction will be recognized for tax purposes one must turn to the law as found in the jurisdiction in which the transaction is consummated. Often that determination will be made without the aid of guiding precedents which are on point and, hence, the effectiveness of a transaction may depend solely on the proper application of general common law or equitable principles. In some instances it will be necessary for the Tax Court to interpret the statutory law of the province. As for the Minister, he must accept the legal results which flow from the proper application of common law and equitable principles, as well as the interpretation of legislative provisions

${ }^{49}$ For example, the ITA at subsection 104(1) provides a supplementary inclusive definition of a "trust" but the ITA itself does not define what a trust is; Fraser $v$ The Queen, 91 DTC 5123 at page 5127 as affirmed 95 DTC 5685 (FCA). The researcher must turn to the common law of trusts and relevant provincial statutes, if any, to understand what a trust is.

${ }^{50}$ Where there is an international element, the researcher may also need to understand the law of other countries. For example, whether a foreign entity is a corporation or some other form of entity, for Canadian tax purposes, will depend on that foreign entity's characteristics under foreign law. 
statutes. ${ }^{51}$ This interaction with other areas of law makes tax law research particularly challenging.

In addition to other legislation and the common law, tax treaties may also be relevant primary sources of law. Tax treaties are negotiated agreements between two nations. As such they are bilateral treaties. ${ }^{52}$ The agreement recorded in the tax treaty is meant to govern the relationship between the two countries with respect to the matters dealt with in the treaty. Tax treaties, like other treaties, do not have the force of law in Canada unless they are incorporated into Canadian law through statute. ${ }^{53}$ Canadian tax convention acts, the acts incorporating tax treaties into Canadian law, generally state that the convention has the force of law in Canada, that in case of any inconsistency between the laws of Canada and the convention the provision of the convention govern, and that if there is any inconsistency between the convention and the Income Tax Conventions Interpretation $\mathrm{Act}^{54}$ the provisions of that act govern. Although most modern treaties are based on the OECD Model Tax Treaty, ${ }^{55}$ each is individually negotiated and must be separately considered. ${ }^{56}$

This portion of the paper will briefly review the ITA and ITR, and then provide guidance on how to read tax provisions found in them. Next, it will providing guidance on how to interpret tax statutes by reference to rules of statutory interpretation, before finishing with some brief guidance on the use, application, and interpretation of tax treaties. ${ }^{57}$

\subsubsection{The Income Tax Act}

The ITA is the primary source of Canadian income tax law - it is the foundation on which the Canadian income tax system is built. If one is unfamiliar with the Canadian income tax system, a good secondary source can help identify the potential legal issues that are raised by particular facts, as well as identify potentially related provisions within the ITA or in other legislation, and point the researcher towards leading cases. However, once the researcher knows what the tax issues are, s/he should always start with the words of the ITA. There really is no

\footnotetext{
${ }^{51}$ For example, the word "sale" has an established legal meaning, and this established meaning was imported into the ITA by the SCC in Will-Kare Paving \& Contracting Ltd v Canada, 200 SCC 36.

${ }^{52}$ This is compared to a multi-lateral treaty which has more than two countries as signatories, with the effect that the relationship with respect to those subject matter's covered are harmonized as among those countries.

${ }^{53}$ For example, Canada-Argentina Income Tax Convention Act, 1994, SC 1994, c 17; Canada-Armenia Income Tax Convention Act, 2004, SC 2005, c 8; or Canada-Colombia Tax Convention Act, 2010, SC 2010, c 15.

${ }^{54}$ RSC 1985, c I-4.

55 Organization for Economic Cooperation and Development, Model Tax Convention on Income and on Capital (OECD: Paris, France, 2014), condensed version available online at http://www.keepeek.com/Digital-AssetManagement/oecd/taxation/model-tax-convention-on-income-and-on-capital-condensed-version-2014 mtc cond2014-en\#page1.

${ }^{56}$ The other common model convention is provided by the United Nations. This convention is more favourable towards source jurisdiction taxation, and therefore more favourable to developing and capital-exporting countries. For a full text copy of the United Nations Model Double Tax Convention between developed and developing Countries, see http://www.un.org/en/development/desa/publications/double-taxation-convention.html.

For a comparison between the OECD Model Convention and the UN Model Convention see Michal Leannard, "The UN Model Tax Convention as Compared with the OECD Model Tax Convention - Current Points of Difference and Recent Developments" (January/February 2009) Asia-Pacific Tax Bulletin 4, available online at http://www.taxjustice.net/cms/upload/pdf/Lennard 0902 UN Vs OECD.pdf.

${ }^{57}$ A detailed description of the interpretation and application of tax treaties is beyond the scope of this paper.
} 
substitute for reading the relevant provisions, in their entirety, with one's issues and objectives in mind. ${ }^{58}$

Reading ITA provisions is not easy task. Practice, perseverance, and persistence are required to become an adept reader of the ITA. In addition to needing to have a solid grasp of the principles of statutory interpretation, ${ }^{59}$ in order to understand the often complex provisions of the ITA, the researcher must be aware that:

- there are many defined terms and phrases, either for the purpose of the Act or for limited purposes; 60

- provisions may contain cross references and exceptions, making it important understand how the various provisions work together;

- the operation of one provision may be affected by other, related, provisions;

- there are certain word-patterns that determine the application of formulas; ${ }^{61}$

- one has to keep in mind the need to consider pending amendments, effective dates, and in-force dates;

- amendments are often retroactive (and sometime retrospective), making it important to look and see what date an amendment is in effective from; ${ }^{62}$ and

- tax issues arise at a particular date and time, and the legislation at that time is the one that will govern (unless future amendments are retroactive). ${ }^{63}$

Given the length of the ITA, knowing how the legislation is structured will allow a researcher to know where to look for potentially relevant provisions. The structure of the ITA follows (mostly) a logical pattern, and is divided into Parts. Part I of the ITA, comprising sections 2 through 180, is the only part that deals with the true Income Tax and is the only part that is further divided into Divisions and subdivisions. The other parts impose distinct taxes in

\footnotetext{
${ }^{58}$ Professor Krishna states that "one must read each provision carefully — at least three times — methodically, and in the context of evolving judicial doctrines of statutory interpretation." Vern Krishna, "Preface", in Fundamentals of Canadian Income Tax, 9th Ed (Thomson Carswell: Toronto, ON, 2006).

59 These are discussed at 3.1.5 "Interpreting Tax Legislation", below.

${ }^{60}$ Defined terms are often found in subsection 248(1), although definitions may be found anywhere in the ITA (at the beginning or end of Divisions, subdivisions, or provisions. The scope and application of these definitions is determined by the opening words of the definition, and not by the location within the ITA where they are located.

${ }^{61}$ The common word patterns found in the ITA are:

- The total of $\mathrm{A}$ and $\mathrm{B}$;

- The lesser of $\mathrm{A}$ and $\mathrm{B}$;

- The greater of $\mathrm{A}$ and $\mathrm{B}$;

- The proportion of $\mathrm{A}$ that $\mathrm{B}$ is of $\mathrm{C}$;

- The amount by which $\mathrm{A}$ exceeds $\mathrm{B}+\mathrm{C}$; and

- $\quad$ A and B versus A or B.

The description of the variables used in formulas are provided by the provision or a related provision. Note that unless otherwise provided, where the result of the application of a formula is a negative value, the ITA deems that value to be Nil by operation of ITA section 257 .

${ }^{62}$ For an excellent article dealing with retroactivity in income tax law, see Thomas McDonnell, QC, "Retroactivity: Policy and Practice" (26 Nov 2006) Proceedings of the Fifty-Eighth Annual Tax Conference (Canadian Tax Foundation: Toronto, ON, 2007).

${ }^{63}$ This means that depending on when the tax issue arose, the researcher may have to do historical research and reconstruct the ITA and other applicable legislation. Such reconstruction is not required for case law, as the case law at the time the dispute is being litigated is what governs.
} 
particular circumstance. ${ }^{64}$ A number of parts apply to the ITA as a whole. These general parts have to be kept in mind whenever one is dealing with provisions in any particular portion. ${ }^{65}$ General Parts include: Part XV, which deals with Administration and Enforcement of the ITA; Part XVI which deals with Tax Avoidance; and Part XVII which deals with Interpretation of the ITA.

Alternatively, rather than consider the Parts of the ITA, we can look at the ITA in a functional manner. Groups of sections could be seen as performing specific functions within the larger scheme of the ITA. For example, liability to tax and computation of income is dealt with by sections 2 to 4 , while business and property income is dealt with in sections 9 to 37 . The author prefers the grouping used by $\mathrm{CCH}$ Canadian, ${ }^{66}$ and reproduced here in Appendix 1. Whatever a researcher's preference, having a list of the ITA's structure will allow him/her to start looking for relevant provisions. ${ }^{67}$

\subsubsection{The Income Tax Regulations}

The ITA, although more detailed than most other legislation, is still relatively general in application. The Income Tax Regulations, ${ }^{68}$ authorized by the ITA ${ }^{69}$ and having the force of law, provide necessary detail and guidance. ${ }^{70}$

One common area where the ITR comes into play is where the ITA prescribed something. ${ }^{71}$ Whenever the ITA uses the term "prescribed" (or a derivative of this), it means that the additional detail is to be found in the ITR. ${ }^{72}$ For example, paragraphs 18(1)(b) of the ITA generally denies deductions on capital account, while Paragraphs 20(1)(a) permits a deduction for such a portion of a capital expenditures for business or property income as is allowed by the ITRs. The researcher will need to look to Part XI of the ITRs dealing with Capital Cost Allowances so as to determine whether, and to what extent, a capital expenditure is deductible.

The ITR is structured using parts (numbered using roman numerals), with the section number of the regulations being a multiple of 100 times the part number of the ITR. The ITRs also contain a number of schedules, the contents of which must be kept in mind. In total there

\footnotetext{
${ }^{64}$ For example. Part II imposes a Tobacco Manufacturers' Surtax, Part IV Imposes a Tax on Dividends Received by Private Corporations; and Part VII deals with Refundable Tax on Corporations Issuing Qualifying Shares.

${ }^{65}$ There are four parts that apply to the ITA as a whole, and they are: Part XV (Administration and Enforcement); Part XVI (Tax Avoidance); Part XVI.1 (Transfer Pricing); and Part XVII (Interpretation).

${ }^{66}$ Canadian Income Tax Act with Regulations, Annotated, 98th Ed (Autumn 2014) (CCH Canadian: Toronto, On, 2014).

${ }^{67}$ For a listing of the general structure of the ITA see http://ita-annotated.ca/RecentDecisions/tax-research/knowthy-ita/the-structure-of-the-ita/.

${ }^{68}$ CRC 1978 c 945 ("ITR").

${ }^{69}$ ITA, supra note 2 at section 221, which sets out a list of matters in regard to which the Governor in Council may make regulations.

${ }^{70}$ Another reason why something maybe found in the ITR rather than the ITA is that it is a matter that is subject to frequent change. Amending regulations is relatively easy through an Order in Council, and allows government to modify details of legislation without having to go through the whole legislative process.

71 For example, paragraph $6(1)(\mathrm{k})$ of the ITA refers to an "amount prescribed" for purposes of calculating an automobile operating expense benefit. This prescribed amount is found in ITR 7305.1.

${ }^{72}$ For example, capital cost allowance (CCA) rates and rules are found in ITR s 1100 . However, just because the ITA refers to something being prescribed does not necessarily mean that the relevant regulation exists.
} 
are 95 parts, comprising over 400 sections, and 10 schedules in the ITR ${ }^{73}$ It is helpful to keep a table of contents for the ITR handy so that you can quickly determine whether you may have to look at particular Parts of the ITR in more detail.

Finally, the authority to make regulations, granted in the ITA, is broad and contains rules that override the general principle that regulations are effective from the date of registration. ${ }^{74}$ Just as with ITA amendments, amendments and additions to the ITR to be outstanding through they will operate (when effective) from the date of announcement (or some other date expressly provided). A researcher will therefore need to be aware of pending amendments as well as effective dates of amendments to the ITR.

\subsubsection{How to Read Income Tax Provisions}

The provisions of the ITA are often long and convoluted. However, given that the ITA should always be the foundation and starting point when forming an opinion as to the law, a researcher must know how to read and understand the ITA's provisions. Although secondary sources and annotated acts can help a researcher understand what provisions may be relevant, the researcher must understand how the law affects a client's circumstances independent from the opinions expressed in these other sources.

What follows is meant to provide the researcher the tools with which to give meaning to the words, phrases, and sentences in ITA provisions, and thereby form an opinion as to the law. The first step in understanding a provision is breaking it down into its operative components (words and/or phrases). This step requires one to exercise judgment and break the provision into 'single-issue' portions. ${ }^{75}$ For example, let us look at subsection 18(2.3): ${ }^{76}$

18(2.3) Notwithstanding subsection 18(2.2), if all of the corporations that are associated with each other in a taxation year have filed with the Minister in prescribed form an agreement whereby, for the purposes of this section, they allocate an amount to one or more of them for the taxation year and the amount so allocated or the total of the amounts so allocated, as the case may be, does not exceed $\$ 1,000,000$, the base level deduction for the year for each of the

\footnotetext{
${ }^{73}$ As at January 13, 2015.

${ }^{74}$ Income Tax Act, RSC 1985, c 1 (5th Supp) at subsection 221(2), where it states that:

A regulation made under this Act shall have effect from the date it is published in the Canada Gazette or at such time thereafter as may be specified in the regulation unless the regulation provides otherwise and it [meet the below conditions].

75 The phrase "single-issue portion" is used to refer to operative components of a provision that can either be attacked or defended in order to succeed. For example, in the example using subsection 18(2.3), the third bullet identified the word "all", meaning that is only some but not all of whatever is referred to are involved, the provision would not apply.

${ }^{76}$ The provisions of the ITA are numbered by sections, and each section may be further divided into subsections, paragraphs, subparagraphs, clauses, and subclauses. The numbering of these further divisions is consistent:

- The first number refers to the section number;

- The second number, in brackets, refers to the subsection;

- The lower case letter, in brackets, refers to the paragraph;

- The lower case roman numerals, in brackets, refer to the subparagraph;

- The upper case letter, in brackets, refers to the clause; and

- The upper case roman numerals, in brackets, refers to the subclause;
} 
corporations is the base level deduction that would be computed under subsection 18(2.2) in respect of the corporation if the reference in that subsection to $\$ 1,000,000$ were read as a reference to the amount so allocated to it.

In breaking up the preceding subsection into single-issue portions, the result would be:

- Notwithstanding subsection $18(2.2)$

- IF

- all

- of the corporations

- that are associated with each other

- in a taxation year

- have filed with the Minister

- in prescribed form an agreement whereby

- for purposes of this section

- they allocate an amount to one or more of them

- for the taxation year

- AND the amounts so allocated OR the total of the amounts so allocated, as the case may be,

- does NOT exceed $\$ 1,000,000$

- $[\mathrm{THEN}]$

- the base level deduction for the year

- for each of the corporations

- is the base level deduction that would be computed under subsection 18(2.2) in respect to the corporation

- IF the reference in that subsection to $\$ 1,000,000$ were read as a reference to the amount so allocated to it.

Notice that CAPS are used to indicate words that indicate conditions, limitations, conjunctions, disjunctions, and results - IF; AND; OR; NOT. This is done to make these important words stand out. Also notice that words have been added in CAPS and [] when needed to make sense of the provision. Broken up in this way, each part of the bulleted portions is one question that may or may not affect the application of the rule and could be formed into self-monitoring questions. An example of a self-monitoring question based on the above example, is: Which corporations are associated with each other?

Another way to break down an income tax provision is to identify operational components of a provision. Operational components are closely related to the components of technical tax provisions, and generally are: ${ }^{77}$

- Persons affected: this identifies the person or persons affected by the provision under examination;

\footnotetext{
${ }^{77}$ Note that each of these components must be present. However, the components may not be found all in one provision, and may be scattered throughout the ITA.
} 
- Receipts Contemplated: this identifies the amounts, transactions, or exchanges of property that are relevant;

- Circumstances contemplated: this identifies the conditions or facts that must be present for the provision to apply;

- Limitations: this identifies the extent of application or exceptions to application of a provision;

- Relevant Period: this identifies the time period(s) that are converged by the provision; and

- Consequences: this identifies the effect of having the provision apply.

After the researcher has broken the provision into its potentially operating potions, s/he can cull out the portions that do not apply to the particular circumstances under consideration. This will allow him/her to focous on the relevant issues, and not waste time on irrelevant matters.

\subsubsection{Interpreting Tax Legislation ${ }^{78}$}

The provisions of the ITA (and other tax legislation) must be interpreted so as to apply to specific facts and circumstances. The courts have developed, and will apply, rules of statutory interpretation to determine the meaning of tax provisions. Understanding these rules will allow a tax researcher to form a reasonable opinion, and alternatives, as to how a court may interpret and apply the law in any particular case. Before we start, the researcher should keep the words of Oliver Wendell Holmes in mind when attempting to assign meaning any synthetically correct string of words: ${ }^{79}$

A word is not a crystal; transparent and unchanged, it is the skin of a living thought and may vary in colour and content according with the circumstances and the time in which it is used.

Statutory interpretation of fiscal legislation, including tax legislation, has evolved over time. When income taxation was still young, ${ }^{80}$ taxation was seen as confiscation of property and strictly interpreted to limit the legislation's reach. ${ }^{81}$ However, the misconception that taxes are

\footnotetext{
${ }^{78}$ For two good, but now somewhat dates articles see David G Duff, "Interpreting The Income Tax Act - Part 1, Interpretive Doctrines" (1999), 47:3 Canadian Tax Journal 464; and David G Duff, "Interpreting the Income Tax Act - Part 2: Toward a Pragmatic Approach” (1999) 47:4 Canadian Tax Journal 741.

${ }^{79}$ Towne $v$ Eisner, 245 US 418 at 425.

${ }^{80}$ Canada's first income taxing statute is generally stated to be the Income War Tax Act, 1917, 7-8 George V c 28. However, in order to fund WWI Canada started taxing business profits through An Act to supplement the Revenue required to meet War Expenditures, (1915) 5 Geo V c 8, and An Act to levy a tax on Business Profits, (1916) 6-7 Geo V c 11. These statutes imposed limited income taxation. The 1917 Act was the first general income tax.

The need to fund the war effort is traditionally provided as being the reason for the introduction of the general income tax in Canada. However, the Parliamentary debated reveal that the Business Profits Tax of 1916, combined with the excises and duties, though with increased rates, would have been able to fund the war effort, but the income tax was introduced in part to spread the tax burden among all taxpayers (not just businesses) and to turn it into a tax that could last well into the future. See House of Commons Debates, Parliament of Canada, $12^{\text {th }}$ parliament $7^{\text {th }}$ session 1917, pages 3761-62.

${ }^{81}$ See the dictum of Lord Cains in Partington $v$ AG (1986), LE 4 HL 100 (HL) at 122, where it was said:

[...] as I understand the principle of all fiscal legislation, it is this: if the person sought to be taxed comes within the letter of the law he must be taxed, however great the hardship may appear to the judicial mind to be. On the other hand, if the Crown, seeking to recover the tax, cannot bring the
} 
impositions, burdens, restrictions of freedoms, usurpations of individual choice, or interference with private property have slowly been replaced with a better understanding of the role of taxation in a modern, market-based, welfare state. ${ }^{82}$ Contemporary courts resort to the "modern rule" of statutory interpretation when interpreting legislation, including the ITA.

\subsubsection{The Modern Rule of Statutory Interpretation}

The modern rule for interpreting tax legislation mirrors the general rule for interpreting legislation generally. ${ }^{83}$ The modern rule is:

[...] the words of an Act are to be read in their entire context and in their grammatical and ordinary sense harmoniously with the scheme of the Act, the object of the Act, and the intention of Parliament. ${ }^{84}$

This is often called the 'textual, contextual, purposive' approach to statutory interpretation. Though easily stated, the operation of this rule of interpretation is often very complex. What is meant by Text? Context? Purpose? How are these various factors to be weighed and when? Courts have tried to provide guidance as to the application of the modern rule to tax legislation, and large textbooks have been written on the topic of statutory interpretation. ${ }^{85}$ However, it has been argued that the SCC's guidance on the application of the

subject within the letter of the law, the subject is free, however apparently within the spirit of the law the case might otherwise appear to be.

Other, non-modern rules, included: (i) plain meaning approach, (ii) purposive approach, and (iii) pragmatic, consequentialist approach.

The change in the nature of taxing statutes was recognized in Stubart Investment Ltd v Canada, [1985] 1 SCR 536, where the court said:

Income tax legislation, such as the federal Act in our country, is no longer a simple device to raise revenue to meet the cost of governing the community. Income taxation is also employed by government to attain select economic policy objectives.

82 See for example Robert Stevens, Law and Politics: The House of Lords as a Judicial Body, 1800-1976 (University of North Carolina Press: Chapel Hill, 1978) where at pages 170-71 the author refers to decisions being influenced by the perception that taxation was the confiscation of property.

${ }^{83}$ Stubart Investments $v$ The Queen, [1984] 1 SCR 536, available online at http://canlii.ca/t/1lpfb. The Supreme Court of Canada adopted the approach put forth in E A Driedger, Construction of Statutes, 2d ed (Butterworths: Toronto, ON, 1983) at $\mathrm{p}$ 87. In the third edition of Driedger on the Construction of Statutes, 3rd ed (Butterworhts: Toronto, 1994) at 132, the rule is expressed in these words:

There is only one rule in modern interpretation, namely, courts are obliged to determine the meaning of legislation in its total context, having regard to the purpose of the legislation, the consequences of proposed interpretations, the presumptions and special rules of interpretation, as well as admissible external aids. In other words, the courts must consider and take into account all relevant and admissible indicators of legislative meaning. After taking these into account, the court must then adopt an interpretation that is appropriate. An appropriate interpretation is one that can be justified in terms of (a) its plausibility, that is, its compliance with the legislative text; (b) its efficacy, that is, its promotion of the legislative purpose; and (c) its acceptability, that is, the outcome is reasonable and just.

${ }^{84}$ E A Driedger, Construction of Statutes, 2d Ed (Butterworths: Toronto, ON, 1983) at p 87, cited in Stubart, supra note 82 at 6323 .

${ }^{85}$ The leading book on statutory interpretation is Ruth Sullivan, Sullivan on the Construction of Statutes, 6th Edition (LexisNexis: Toronto, ON, 2014).

For papers dealing expressly with the interpretation of tax statutes, see: Jinyan Li and David Piccolo, "Reviving the Modern Rule in the Interpretation of Tax Statutes: Baby Steps Taken in Canada Trustco, Mathew, Place Dome and 
modern rule to tax legislation is inadequate, leaving many important questions unanswered. ${ }^{86}$ This paper is providing only a brief overview of the rules of statutory interpretation.

In addition to the modern rule, it is important to remember that both the French and English versions of federal legislation are equally authoritative, ${ }^{87}$ and that federal legislation must be interpreted in light of the Interpretation Act, ${ }^{88}$ section 12, directive that "[e]very enactment is deemed remedial, and shall be given such fair, large and liberal construction and interpretation as best ensures the attainment of its objects". ${ }^{89}$ The modern rule is not easy to apply, and various factors need to be taken into account. These factors are often found in the various, older, approaches to and rules of statutory interpretation. These older rules are discussed at the end of this portion of the paper (at 3.1.5.3).

A brief outline of the history of the SCC's flirtation with the modern rule in the tax context seems appropriate. The modern rule was first expressly adopted by the SCC in Stubart, ${ }^{90}$ where it was said that tax statutes are to be interpreted in the same manner as other statutes. The Stubart decision was followed in Bronfman, ${ }^{91}$ where the Court rejected a taxpayer's argument on the basis of Parliament's intention when enacting the provisions in question. Despite this strong start and the continued reference to the modern rule, the SCC reduces the effect of the modern rule by taking what is known as the "plain meaning" approach. The move away began with the decision in Antosko, ${ }^{92}$ where the Court held that a taxpayer was entitled to rely on the "clear and plain" meaning of the statute when they applied to the taxpayer's circumstances absent the object and purpose of the provision. ${ }^{93}$ The plain meaning approach was also followed in Friesen, ${ }^{94}$ where the Court said that object and purpose only become relevant when the text of provision "admits of some doubt or ambiguity" - essentially equating the modern rule with the older plain meaning rule. ${ }^{95}$ The SCC appeared to be set on this two part application of the modern rule when interpreting tax legislation and again applied it in Ludco. ${ }^{96}$

The first GAAR case to come before the SCC appears to have given life again to the modern rule proper. In Canada Trustco, ${ }^{97}$ the SCC reaffirmed the modern rule's application and said that the "interpretation of a statutory provision must be made according to a textual,

Imperial Oil" (2007) 3:6 CLPE Research Paper 31/2007; Brian Arnold, "The Supreme Court and the Interpretation of Tax Statutes - Again" (2006) 54 Canadian Tax Journal 677; and David G Duff, "Justice Iacobucci and the "Golden an Straight Metwand" of Canadian Tax Law" (2007) 57 University of Toronto Law Journal 525.

${ }^{86}$ Jinyan Li and David Piccolo, "Reviving the Modern Rule in the Interpretation of Tax Statutes: Baby Steps Taken in Canada Trustco, Mathew, Place Dome and Imperial Oil" (2007) 3:6 CLPE Research Paper 31/2007.

${ }^{87}$ Charter of Rights and Freedoms, Schedule B, Canada Act, 1982, subsection 18(1), and Official Languages Act, SC 1985, c 31 (4th Supp), sections 6, 7, and 13. Courts will attempt to find an interpretation that is in line with both versions.

${ }^{88}$ Interpretation Act, RSC 1985 c -21.

${ }^{89}$ Another important rule of interpretation provided in the Interpretation Act, is that words and phrases that are defined in a statute have the same meaning in the regulations authorized by that statute.

${ }^{90}$ Stubart Investment Ltd v Canada, [1984] 1 SCR 536 ("Stubart").

${ }^{91}$ Bronfman Trust v The Queen, [1987] 1 SCR 32 ("Bronfman").

${ }^{92}$ Canada v Antosko, [1994] 2 SCR 312 (“Antosko).

${ }^{93} \mathrm{Ibid}$, at para 25.

${ }^{94}$ Friesen v Canada, [1995] 3 SCR 103 (“Friesen”).

${ }^{95} \mathrm{Ibid}$, at para 60.

${ }^{96}$ Ludco Enterprises Ltd v Canada, 2001 SCC 62 ("Ludco")

${ }^{97}$ Canada Trustco Mortgage Co v Canada, 2005 SCC 54 ("Canada Trustco"). 
contextual and purposive analysis to find a meaning that is harmonious with the Act as a whole". 98 The court recognized that the relative weight to be given to each of the three elements may vary depending to the extent and level of ambiguity in the provision being interpreted. Where the words are" precise and unequivocal, the ordinary meaning of the words play a dominant role", 99 but "where the words can support more than one reasonable meaning, the ordinary meaning of the words plays a lesser role". ${ }^{100}$ The difference between this version of the modern rule and the plain meaning approach to the modern rule is the emphasis of applying all three criteria at all times, as "in all cases the court must seek to read the provision of an Act as a harmonious whole". ${ }^{101}$ That said, the Court emphasized that because of the explicit detailed provisions dominating the ITA, and its role in economic and business planning, provisions must be interpreted so as to "achieve consistency, predictability, and fairness so that taxpayers may manage their affairs intelligently". ${ }^{102}$ In Canada Trustco the court is ambivalent in the robust application of the modern rule to 'usual' ITA provisions while being clear that the robust analysis applies to GAAR. In Mathew, ${ }^{103}$ another GAAR case, the court determine the meaning of two provisions used in concert by the taxpayer to in effect sell losses by applying a robust modern rule. The Court recognize that it may be "useful to consider the three elements of statutory interpretation separately to ensure that each has received its due, [the Court expressly stated that these elements] inevitably intertwine". ${ }^{104}$ Note that in Mathew the court truly intertwined all three elements, and even under the textual element purposive interpretation was use to ensure that the interpretation of one provision considered related provisions. ${ }^{105}$

Placer Dome ${ }^{106}$ took the modern rule squarely beyond the GAAR provisions and into the realm usual ITA provisions and provisions of provincial taxing statutes. However, the SCC in Placer Dome appears to have retreated towards textual pain meaning preference for taxing statutes when it stated that where "a provision admits to no ambiguity in its meaning or in its application to the facts, it must simply be applied". ${ }^{107}$ That said, the Court, after fining ambiguity, looked to the entire statute and used presumed legislative purpose drawn from the presumption against tautology and against absurdity. The SCC now always cites the modern rule as applicable in tax cases, ${ }^{108}$ but its application can sometimes leave the researcher confused as to the relative weight to be given to each of the three elements. ${ }^{109}$ The different interpretations

\footnotetext{
${ }^{98} \mathrm{Ibid}$, at para 10.

${ }^{99} \mathrm{Ibid}$, at para 10.

${ }^{100} \mathrm{Ibid}$, at para 10.

${ }^{101} \mathrm{Ibid}$, at para 10.

${ }^{102} \mathrm{Ibid}$, at para 12 .

${ }^{103}$ Mathew v Canada, 2005 SCC 55 ("Mathew").

${ }^{104}$ Ibid, at para 43.

${ }^{105} \mathrm{Ibid}$, at 46.

${ }^{106}$ Placer Dome Canada Ltd. v. Ontario (Minister of Finance), 2006 SCC 20 (“Placer Dome”).

107 Ibid, at para 23.

${ }^{108}$ See for example A.Y.S.A. Amateur Youth Soccer Association v. Canada (Revenue Agency), 2007 SCC 42; Lipson v Canada, 2009 SCC 1; Copthorne Holdings Ltd v Canada, 2011 SCC 63; Dube v Canada, 2011 SCC 39; Bastien Estate $v$ Canada, 2011 SCC 38; and Canada $v$ Craig, 2012 SCC 43.

${ }^{109}$ For example, the SCC in Imperial Oil Ltd v Canada, 2006 SCC 46, the SCC agreed on the application of the modern rule but the court split as to relative weight to be given to the elements, with the dissent strongly emphasizes the textual element and described the tax rules as "rules of engagement" that apply to the "battlefield on which over 21 million Canadian taxpayers engage with the Minister". The dissents comments belie a misunderstanding of the role of taxation in modern Canadian society.
} 
and weights given to the three elements by the dissent and majority in Imperial Oil, for example, demonstrate the difficulty of applying the modern rule. ${ }^{110}$

Where does this leave the researcher? We know that text, context, and purpose must be taken into account in all interpretative exercises, and that the goal is to use these three elements so as to arrive at an interpretation that is harmonious with the entire scheme of the ITA. We also know that the three elements are intertwined such that each element may have an influence on the application of the other two. In this paper, the following suggestions are made when looking at text, context, and purpose as part of an interpretive exercise.

The textual element requires the reader to form an opinion as to the ordinary meaning of the words used in the relevant provision(s). This ordinary meaning is often the first impression formed when the text is read through. ${ }^{12}$ However, the ordinary meaning is not the dictionary meaning of words or even the common meaning of words. The ordinary meaning of words is informed by the context, including the subject matter being addressed, such that the ordinary meaning can be either the dictionary meaning, ${ }^{113}$ the common meaning, ${ }^{114}$ the legal meaning, ${ }^{115}$ or the technical meaning. ${ }^{116}$ Which one of these meanings, or what combination of them, inform the "ordinary meaning" of an ITA provision will depend on the context of the provision. The textual element will be given greater weight where:

- The provision is drafted in great detail, and the words used are concrete and precise ${ }^{117}$

- The provision is directed at a specialized subgroup of the public; and

- Where the importance of certainty and predictability are of paramount and legitimate concern.

The contextual element has a number of facets. The interpretive context includes:

\footnotetext{
${ }^{110}$ For a thorough analysis of the differences between the dissent and the majority when applying the modern rule see Jinyan Li and David Piccolo, "Reviving the Modern Rule in the Interpretation of Tax Statutes: Baby Steps Taken in Canada Trustco, Mathew, Place Dome and Imperial Oil" (2007) 3:6 CLPE Research Paper 31/2007, at pp $34-40$.

${ }^{111}$ This approach is generally supported by the comments of Ruth Sullivan in her leading book Sullivan on the Construction of Statutes, 6th Edition (LexisNexis: Toronto, ON, 2014).

${ }_{112}$ Canadian Pacific Air Lines Ltd v Canadian Air line Pilots Association, [1993] 2 SCR 724 at 735.

${ }^{113}$ A dictionary provides an acontextual range of senses in which a word is used in a particular linguistic community (British, Canadian, American, etc).

${ }^{114}$ The common meaning refers to the meaning assigned by a reader based on that reader's personal context. This is at best a hypothetical meaning that does not consider the other senses of the word that may arise from other contexts. For example, a woodworker will assign a different meaning to the word "property" than would a property lawyer, and a property lawyer would assign a different meaning to the word "property" than would a tax lawyer.

${ }^{115}$ Some words have been defined in jurisprudence to have particular meaning or are defined by related and relevant statutes to have specific meanings.

${ }^{116}$ Certain words have particular meanings when used in the context of particular professions, activities, or communities. For example the word "car" would have a different meaning when used in the construction community (meaning a piece of heavy equipment) than in the veterinarian community (a feline and common pet).

${ }^{117}$ In Canada Trustco, supra note 97, at para 11, the SCC stated that the "particularity and detail of many tax provisions have often lead to an emphasis on textual interpretation", and as such, "where Parliament has specified precisely what conditions must be satisfied to achieve a particular result, it is reasonable to assume that Parliament intended that taxpayer would rely on such provisions to archive the results they prescribe".
} 
- The internal or literary context, which is made up of the text and grammatical structure of the provision, and moves out to include related provisions, the placement of the provision within the lager structure of the legislation, the relationship of the provision to all of the provisions in the statute, the and the entire statute book;

- The legal context, which includes the legislative history of the provision(s) being interpreted, the existing case law in relation to the words and phrases used in the provision, the common law background against which the provision operates, related statutes, the constitution, international treaties, and international law; ${ }^{118}$ and

- The external context, which includes the reasons for the statute or provisions existence (social, economic, and/or political), the historical circumstances surrounding the enactment or amendment(s), the social setting in which the statute is meant to operate, the social institutions through which the statute achieves its objectives, and malice or need that the statute or provision is meant to respond to, and the general cultural context of the jurisdiction in which the statute operates.

Each of these facets must be considered, be the relative weight given to each facet will differ on the circumstances of the interpretive exercise. Larger contextual lenses will gain greater prominence when interpreting the provision(s) the wider and more general the provision is in its operation and intended target audience, and the less detailed and technical the provision is. However, the relevance and weight of each of the various contextual lenses, and their appropriate mix, appears to depend on subjective assessments of factors that may make each context relevant and meaningful or not.

The final factor requires the researcher to ponder where statutory purpose/intention comes from and how it is identified? The reasoning for this analysis comes from the presumption that all statutes and provisions within them have a purpose. ${ }^{119}$ The court's duty is to discover the purpose. In Canada Trustco, the SCC considered: ${ }^{120}$

\footnotetext{
${ }^{118}$ In Manrell $v$ Canada, 2003 FCA 128, at para 28 and 48, the Federal Court of Appeal included the legislative history of the provision and the case law interpreting words used in the provision as part of the legal context.

${ }^{119}$ The historical roots of referring to purpose in interpreting statutes lies in Heydon's Case (1584) 76 ER 637, which set out the mischief rule, and stated at 638 :

For the sure and true interpretation of all statutes in general (be they penal or beneficial, restrictive or enlarging of the common law) four things are to be discerned and considered:

$1 \mathrm{st}$. What was the common law before the making of the Act.

2 nd. What was the mischief and defect for which the common law did not provide.

3 rd. What remedy the Parliament hath resolved and appointed to cure the disease of the commonwealth.

And 4 th. The true reason of the remedy; and then the office of all the Judges is always to make sure construction as shall suppress the mischief, and advance the remedy, and to suppress subtle inventions and evasions for continuance of the mischief, and pro privato commodo, and to add force and life to the cure and remedy, according to the true intent of the makers of the Act, pro bono publico.

${ }^{120}$ Canada Trustco, supra note 97 at paras 74-75. This was also done in Mathew, supra note 103 at paras 48-54, with a particular focous on the general policy of the ITA towards transfer of losses between arm's length taxpayers.
} 
- The express, clear and plain purpose/intention on the basis of the enacted words in the provision; ${ }^{121}$

- The implicit purpose/intention derived from the ITA's broader treatment of specific kinds of circumstances, the relationship between the provision and related provisions, and the legislative history of the provision that are reasonably implied on the basis of the enacted words; ${ }^{122}$

- The presumed purpose/intention ${ }^{123}$ assigned to legislative actions absent an indication to the contrary, for example that of promoting certainty and predictability in financial and tax matters; ${ }^{124}$ and

- The express stated purpose/intention by the legislature as identified through records of legislative debate, technical notes accompanying introduction and changes in legislation, government reports, and the like.

It appears from Mathew that when two or more provisions have to be interpreted because their interaction is giving rise to the tax controversy before the court, then the combined purposes of the various provisions must be considered. ${ }^{125}$ Where the purpose/intention behind the statute or provision is sufficiently clear, such an identified purpose may be given significant weight even in circumstances where the text appears to have a clear and unambiguous meaning in odds with that purpose. Note that a provision or statute may be informed by a mix of purposes, and the appropriate mix and balance between the components must be struck as part of the interpretive exercise.

${ }^{121}$ The ordinary meaning is not itself a dictionary meaning, but is the contextual ordinary meaning. For example, in Placer Dome, supra note 106, the SCC determined the ordinary meaning of "hedging" by referring to Generally Accepted Accounting Principles and Canadian court decisions.

${ }^{122}$ See Mathew, supra note 103 at para 51. However, the SCC in A.Y.S.A. Amateur Youth Soccer Association v. Canada (Revenue Agency), 2007 SCC 42, at paragraph 15, noted that although implied purpose is part of the modern rule, "arguments based on implied purpose must be viewed with caution". This was based on the statement of the SCC in Shell Canada Ltd v Canada, [1999 [ 3 SCR 622 at para 43, where the court noted that the ITA "is a complex statute through which Parliament seeks to balance a myriad of principles. This Court has consistently held that courts must therefore be cautious before finding within the clear provisions of the Act an unexpressed legislative intention."

This can include the relationship between the common law and the ITA provisions, supported by Hansard. The majority of the SCC in A.Y.S.A. Amateur Youth Soccer Association v. Canada (Revenue Agency), $2007 \mathrm{SCC} 42$, at paragraph 12 rejected the government's argument that the ITA provision occupied the filed and provided a complete code for sports associations and stated that Parliament intended to leave non-expressly mentioned sports associations' eligibility for charitable status to be determined according to the common law of charity. The SCC differentiated between parliament 'extending' the common law definition of charity and using an alternative mechanism to achieve its social purpose.

${ }^{123}$ The presumed purpose also includes several rules of statutory interpretation that result from conventions of statutory drafting, including the presumption against unconstitutionality and the presumption against tautology. The presumption against tautology was used by the SCC in Placer Dome, supra note 106, at para 44, and the presumption against absurdity was used at para 52 .

The presumed purpose also includes the entire body of accepted legal norms as they evolve from time to time.

${ }^{124}$ Note that in Jinyan Li and David Piccolo, "Reviving the Modern Rule in the Interpretation of Tax Statutes: Baby Steps Taken in Canada Trustco, Mathew, Place Dome and Imperial Oil" (2007) 3:6 CLPE Research Paper 31/2007, the authors wondered, at page 20 , to what extent the principle of certainty, predictability and fairness overrides purposive interpretation" and noted that "if the court is more persuaded by the need for certainty and the taxpayer's right to legitimate tax minimization, the scope of purposive interpretation in affected".

${ }^{125}$ Mathew, supra note 103 at para 55. 
In summary, given the nature of taxation and the need for certainty and predictability in financial affairs, and taxpayers' reasonable expectation that they are able to order their affairs in reliance to the clear meaning of statutory provisions, a court will likely: ${ }^{126}$

- Give the text of the provision greater weight where the words of the statute are precise, clear, and unequivocal;

- Give the context and purpose of the provision greater weight when the provision is open to more than one reasonable interpretation; and

- In all cases come only to an interpretation that can be born by the words used in the provision, and can reasonably fall within the scheme and object of the act. ${ }^{127}$

\subsubsection{Drafting Conventions}

Those tasked with reducing the will of law-makers to writing are presumed to use words and phrases in a manner that accords with the conventional use of those words and phrases in the statute book generally. As with any presumption, express words of or implication from the words of the statute may displace these presumptions. What follows is only a sample of statutory drafting presumptions. ${ }^{128}$ For more exhaustive treatment consult texts on legislative drafting. Legislative drafting conventions include:

- Statutes are presumed to have a logical organization, usually from the general to the particular;

- Where a statute is divided into parts, the parts of the legislation are presumed to be distinct;

- The statute is presumed to not use redundant words, such that all words are presumed to have meaning;

- The same word is presumed to be used consistently, and carry the same meaning, throughout a statute;

- Different words are presumed to have different meanings throughout the statute;

- The word "shall" is presumed to indicate the imposition of a duty (mandatory), or when used with "not" or "no" a prohibition;

- The word "may" is presumed to confer or indicate a power, right, or choice, though the power granted may have to be exercised once the conditions of the granting of the power are present;

\footnotetext{
${ }^{126}$ Anti-avoidance provisions and provisions providing social benefits will generally receive a wider, more liberal, and purposive interpretation than provisions setting tax liability and imposing penalties. See for example ...

127 in ATCO Gas \& Pipelines Ltd V Alberta (Energy \& Utilities Board), [2006] 1 SCR 140 at para 48, the Court stated that "the grammatical and ordinary sense of a section is not determinative and does not constitute the end of the inquiry" but that a court "is oblige to consider the total context of the provisions to be interpreted, no matter how plain the disposition may seem upon initial reading".

${ }^{128}$ See for example Helen Xanthaki, Thornton's Legislative Drafting (Bloomsbury Professional: West Sussex, UK, 2013); or Elmer A Driedger, Materials on Legislative Drafting (University of Ottawa: Ottawa. See also: Uniform Law Conference of Canada, Report of the Committee Appointed to Prepare Bilingual Legislative Drafting Conventions for the Uniform Law Conference of Canada (Uniform Law Conference of Canada: Ottawa, ) available online at http://www.ulcc.ca/en/uniform-acts-en-gb-1/546-drafting-conventions/66-drafting-conventions-act; and Government of Canada, Guide to Making Federal Acts and Regulations, 2nd ed (Privy Council: Ottawa, 2001), available online at http://www.pco-bcp.gc.ca/docs/information/publications/legislation/pdf-eng.pdf.
} 
- The word "or" can be conjunctive or disjunctive (only when one of a set of criteria are required for the rule to apply);

- The word "and" is conjunctive (indicate that all criteria have to be met before the rule applies);

- The word "means" indicated an exhaustive definition of a term;

- The word "includes" has two uses, either indicating an open-ended definition or expansive definition of a term that builds on the ordinary meaning of that term, or alternatively providing un-exhaustive specific examples of the defined terms meaning;

- Where a word or phrase has a legal meaning as determined by the courts, that meaning is presumed to have been intended and will prevail over the ordinary meaning;

- Where a word has a different legal meaning commercial and non-commercial contexts, for ITA purposes it is presumed that the legal meaning in the commercial context will prevail over the legal meaning in the non-commercial context;

- Where a word or phrase is defined in the ITA, that definition will prevail over the ordinary or other legal meanings (not with reference to the ITA and that definition); and

- Where a word or phrase is defined to have a particular meaning for a particular or limited circumstance of the ITA, that specific meaning will dominate a general definition for that particular or limited circumstance.

\subsubsection{Maxims of Statutory Interpretation}

Maxims of statutory interpretation have been developed by judges over time in response to the reality that certain features of legislation repeatedly reappear. On the basis of this observed recurrence, inferences relating to these legislative features also tend to recur. There is overlap between some of the maxims and the presumptions based on statutory drafting conventions, and just like the presumptions offer a tentative position for statutory interpretation. What follows is a listing of only some of the common maxims: ${ }^{129}$

- Noscitur a Sociis (one is known by one's associates) - in a string of words within a provision the meaning of a doubtful word can be derived from its association with the other words, such that each word is given meaning;

- Ejusdem generis (of the same kind) - Where a list of specific classes of persons or things is followed by a general term, the general statement is presumed to be limited to items of the same type as those specifically enumerated;

- Expressio unius est exclusio alterius (the expression's mention of one thing excludes all others) - Where a list of specific classes of persons or things are provided, but others that are similar are not listed, the presumption is that those items not expressly listed are meant to be excluded;

- In pari materia (upon the same subject) - When a meaning is ambiguous, the meaning may be determined by referring to meanings found in the rest of the statute (based on the presumption that the same word has the same meaning throughout a statute);

\footnotetext{
${ }^{129}$ For a list of latin maxims and phrases see John N Notterell, A Collection of Latin Maxims and Phrases (Stevens and Haynes: London, 1913), available online at https://archive.org/stream/cu31924021688670/cu31924021688670 djvu.txt.
} 
- Generalia specialibus non derogant (the general does not detract from the specific) - When a general rule/legislation is provided and its operation interferes with a specific rule/legislation, the specific prevails; and

- Parliament does not speak in vain - every word in a statute should be given meaning, and no interpretation should render contents mere surplusage or meaningless.

\subsubsection{Older Rules of Statutory Interpretation}

There are various other, older, approaches to interpreting statutes. Each of these other approaches may have something to contribute when interpreting provisions of the ITA, but only as particular applications of the three elements of the "modern rule". When reading older cases you may come across these rules being used by the courts in interpreting the ITA. Where these old interpretations are not in your favour, you may be able to challenge them if a full textual, contextual, and purposive analysis would suggest that the older interpretation is no longer correct. These older approaches include: (i) the literal meaning approach, (ii) the plain meaning approach, (iii) the rule to avoid absurd, unjust, or anomalous results, (iv) the mischief rule, (v) the legislative intention rule, (vi) the purposive approach, (vii) the pragmatic or policy approach, (viii) the use of extrinsic evidence.

(i) The Literal Meaning Approach ${ }^{\mathbf{1 3 0}}$ - This approach asks the person interpreting to look at the clear and literal meaning of terms used in the ITA. This approach assumes that every word has one particular meaning. However, where there is any ambiguity, the ambiguity is resolved in favour of the taxpayer where the provision is a charging provision $^{131}$ and in favour of the Crown where the provision is a relieving provision, exemption, or deduction. ${ }^{132}$ This approach ignores the spirit of the law, the scheme of the Act, the object of the Act, and the intention of Parliament. This rule has been supplanted in most cases by the modern rule, though courts may still make reference to it when dealing with very detailed provisions.

(ii) The Plain Meaning Approach ${ }^{\mathbf{1 3 3}}$ - This approach asks the person interpreting to give the words used their ordinary meaning (absent ambiguity). Where there is ambiguity, the court will need to refer to the scheme and object of the Act or the intention of parliament to resolve the ambiguity. This is different from the literal meaning approach in that words are not assumed to have one meaning but a range of meanings, with the particular meaning having to be determined by reference to the internal context. This approach has fallen out of favour for two reasons. ${ }^{134}$ The first reason is that the approach does not give any weight to discretion granted to courts by parliament and, thereby, ignores that words

\footnotetext{
${ }^{130}$ See for example the decisions in MNR v MacInnes, [1954] CTC 50 (Ex Ct); and Tennant $v$ Smith, [1892] AC 150 .

${ }^{131}$ See Fries $v$ The Queen, [1990] 2 CTC 429 (SCC) at 439.

${ }^{132}$ The asymmetry was rejected by the SCC in Corporation Notre-Dame de Mon-Secours $v$ Communaute Urbaine de Quebec et al, 95 DTC 5017 (SCC) at 5022, and the court held that any ambiguity would be resolved in favour of the taxpayer.

${ }^{133}$ See for example the decisions in Lumsden $v$ Inland Revenue Commissioners, [1914] AC 877 (HL) at 896-97; and $R v$ McIntosh, [1995] 1 SCR 686.

${ }^{134}$ Note that the SCC in Stubart Investments Ltd v The Queen, [1984] 1 SCR 536, stated that the "plain meaning rule" should continue to be applied, but in a substantive sense so that if a taxpayer is within the spirit of the provision, the provision should apply.
} 
do not have a natural meaning, only usages. The second is that it is inconsistent with section 12 of the Interpretation Act. ${ }^{135}$

(iii) The rule to avoid absurd, unjust, or anomalous results ${ }^{136}$ - This rule requires that the person interpreting the statute construe a provision so as to avoid irrational or unjust outcomes. This is so even if the language of the statute appears to be heading in the direction of those undesirable outcomes. This rule is often applied where there is a sensible alternative available.

(iv) The mischief rule (37 $^{\mathbf{1 3}}$ - This rule requires that the person interpreting the provision inquire what mischief or defect the legislation is attempting to address or cure. Once the mischief is identified, the provision must then be interpreted so as to deal with the mischief and provide a remedy. This is the rule that is codified in section 12 of the Interpretation Act. ${ }^{138}$

(v) The legislative intention rule $^{139}$ - This rule requires that the person interpreting the provision attempt to give the meaning to the statute that the legislature would have given that provision if they would have been faced with the particular facts and circumstances before the court. The legislatures intentions can be gleaned from records of debates, and other government documents related to the drafting of the particular provision. However, it is impossible to assign intention to a collective, diverse, legislative body whose members are likely not completely familiar with the content and complexity of the statute they are enacting or amending.

(vi) The purposive approach ${ }^{\mathbf{1 4 0}}$ - This approach asks the person interpreting the provision to decipher the social and policy goals that the provision is attempting to advance or promote. It looks at the reason(s) the statute was enacted and asks courts to interpret and apply the provision so as to achieve the legislative purpose. However, as with legislative intention, the purpose of legislation is not always easy to determine. This approach may lead to inconsistent or uncertain applications of the provision.

(vii) The pragmatic or policy approach ${ }^{141}$ - This approach asks the person interpreting the provision to set out and examine the alternative policy implications of possible interpretations (the impact of alternative interpretations on equity, neutrality, and simplicity). The court would then choose the interpretation that yields the most appropriate policy outcome. To employ this approach, the researcher must use and apply tax policy analysis tools, and aims for a dynamic interpretation of tax law. This interpretive approach is thought to be most consistent with democratic values, to operate as a damper to interest-group influence on legislative rule making, and to promote consistency with the policy goals that animate tax legislation.

(viii) The use of extrinsic evidence - This approach asks the person interpreting the provision to consider the context of the provision by looking at sources outside of the statute. The

\footnotetext{
${ }^{135}$ RSC 1985, c I-21.

${ }^{136}$ See for example the decisions in Grey v Pearson (1987), 10 ER 1216 (HL). See also the Canadian decision in Moldowan v The Queen, [1977] CTC 310 (SCC).

${ }^{137}$ See Heydon's Case 01584), 76 ER 637 (KB) at 638.

${ }^{138}$ RSC 1985, c I-21.

${ }^{139}$ See for example the decisions in Cartwright $v$ City of Toronto (1914), 50 SCR 215 at 219; and Attorney-General $v$ Carlton Bank, [1899] 2 QB 158 (CA) at 164.

${ }^{140}$ See for example the decision in Smith $v$ Attorney General of Canada (1924), 1 DTC 45 (Ex Ct).

${ }^{141}$ See for example Corporation Notre-Dame de Mon-Secours v Communaute Urbaine de Quebec et al, 95 DTC 5017 (SCC).
} 
relevant context can include legislative materials (Hansard, Budget Speech, Budget Documents, Committee Reports, Explanatory Notes, and Press Releases), the legislative evolution of the provision (if any), and the social and economic context of the statute generally and the provision specifically.

\subsubsection{Additional Considerations}

In addition to applying the rules of statutory interpretation in giving meaning to words and phrases, ${ }^{142}$ the ITA provides internal definitions of words and phrases, makes extensive use of cross-references, uses 'deeming provisions', and provides 'prescribed' details in the ITR. These features must be considered when interpreting a provision. All of these must be kept in mind when interpreting the ITA.

The ITA defines a large number of words and phrases, some of them in ways that are not intuitive or part of normal English usage. ${ }^{143}$ Although many definitions are found in the definition part of the ITA, ${ }^{144}$ predominantly in subsection $248(1)$, definitions are also found in other parts, divisions, subdivisions, and sections of the ITA. It is important to be aware that the application of a definition is not limited to the position in the ITA in which it is located, but rather is limited by the words used in the definition itself. ${ }^{145}$ Other terms found in the ITA are defined in the Interpretation Act $^{146}$ for purposes of all Federal statutes. ${ }^{147}$

The researcher will find that the ITA often uses cross-references to other provisions in the ITA (in the same section or other sections) or cross-references to other statutes. It is impossible to understand the full import of a provision containing a cross-reference without following the trail fully. When conducting research, it is important to read-in the words of the cross-reference into the provision.

Deeming provisions ${ }^{148}$ are used to remove ambiguity or to create legal fictions in particular circumstances. ${ }^{149}$ Legal fictions created by deeming provisions may either supplant

${ }^{142}$ A great resource for judicial interpretations of tax words and phrases see Mark Jolin, Canada Tax Words, Phrases, and Rules, loose-leaf (Carswell: Toronto, ON, 1990). This resource provides judicially considered tax words and phrases daring from 1917 onward.

143 For more see "Defined Terms", available online at http://ita-annotated.ca/RecentDecisions/taxresearch/interpreting-the-ita/internal/defined-terms/

${ }^{144}$ ITA, supra note 2 at Part XVII

${ }^{145}$ For example: "for purposes of the Act"; "for purposes of this section"; "for purposes of this Part"; and so on.

146 RSC 1985, c I-21, subsection 35(1), contains a long list of definitions, including for "bank", "Canada", "corporation", "month", and "person".

147 Another common reference to the Interpretation Act is for purposes of definitions of time and dates found in section 26.

${ }^{148}$ For a great article on the different uses of deeming provisions see MN Kandev and J Lennard, "Interpreting and Applying Deeming Provisions of the Income Tax Act" (2012) 60:2 Can Tax J 275. See also "Deeming Provisions" available online at http://ita-annotated.ca/RecentDecisions/tax-research/interpreting-the-ita/internal/deemingprovisions/.

${ }^{149}$ See $R v$ Verrerre, [1978] 2 SCR 838, where the court stated:

[...] A deeming provision artificially imports into a word or an expression an additional meaning which they would not otherwise convey beside the normal meaning which they retain where they are used; it plays a function of enlargement analogous to the word "includes" in certain definitions; however, "includes" would be logically inappropriate and would sound unreal because of the fictional aspect of the provision. [...] 
reality or they may merely supplement reality. They can serve one of four (4) functions, making it important to understand the effect and function of particular deeming provisions. These four functions are: ${ }^{150}$

- To create a legal fiction by declaring that something exists, has certain properties, or has occurred regardless of the truth of the matter;

- To declare the law;

- To create a legal presumption by declaring that certain facts are to be taken as established; and

- To confer a discretion.

Courts generally interpret and apply deeming provisions narrowly. This means that unless facts and circumstances fall squarely within the express words of a deeming provision, courts will not impute the operation of the deeming provision (or the corollary of the deeming provision).

As mentioned above, the ITA provides additional detail, when required, by using the term "prescribed". ${ }^{151}$ When used, "prescribed" refers to the Regulations ${ }^{152}$ or one of the prescribed forms. When this term is encountered, it is necessary to look to these other source so as to understand the legal effect of the particular provision. ${ }^{153}$ Regulations are there to either provide detail that goes beyond what is needed from Parliament, or it is used to provide for matters that need to respond to changing circumstances. ${ }^{154}$

\subsubsection{Tax Treaties}

Double Tax Conventions are negotiated agreements between two countries that determine how potential disputes will be resolved when both countries may exert jurisdiction to tax a certain receipt. Although most of Canada's tax treaties are based on the OCED Model Treaty, ${ }^{155}$ a researcher must always refer to the specific tax treaty in force between Canada and another country. ${ }^{156}$

${ }^{150}$ See R Sullivan, Sullivan on the Construction of Statutes, 5th ed (LexisNexis: Markham, ON, 2008).

${ }^{151}$ The Income Tax Regulations, CRC 1978 c 945, are authorized by the ITA, section 221, which states that: The Governor in Council may make regulations [...] prescribing anything that, by this Act, is to be prescribed or is to be determined or regulated by regulation.

${ }^{152}$ CRC 1978 c 945.

${ }^{153}$ Note that a prescribed form, even if mandatory, does not have the effect of overriding or being inconsistent with the ITA or Regulations.

${ }^{154}$ Regulations are much easier and quicker to pass as they are promulgated by the Governor General on the advice of the Privy Council (the Cabinet), and there is no need to go through the formalities of passing a Bill through parliament.

${ }_{155}$ Organization for Economic Cooperation and Development, Model Tax Convention on Income and on Capital (OECD: Paris, France, 2014), condensed version available online at http://www.keepeek.com/Digital-AssetManagement/oecd/taxation/model-tax-convention-on-income-and-on-capital-condensed-version-2014 mtc cond2014-en\#page1.

${ }^{156}$ Canada has over 92 tax treaties in force. For a complete list of all of Canada's tax treaties in force see the Department of Finance listing available online at http://www.fin.gc.ca/treaties-conventions/in force--eng.asp.

Note that as part of international tax planning, you may have to consider treaties between countries other than Canada. When making use of various jurisdictions and their double tax conventions, you must be aware of the 
Tax treaties have two main purposes: (i) to reduce or eliminate double taxation, ${ }^{157}$ and (ii) to prevent fiscal evasion. ${ }^{158}$ Tax treaties do not impose taxes, but rather serve to divide up the tax pie as between the two countries, limiting those countries' ability to, or extent of, taxation of certain items. In other words, they provide relief to taxpayers in certain circumstances. Their operation may result in double-non-taxation of certain receipts. Treaties only provide relief for those taxes to which the treaty applies and only to those persons for whom relief is contemplated.

When reading a tax treaty the researcher will notice that the treaty use "article" rather than "section". This difference is one of nomenclature only. Each article will deal with a distinct issue or a set of related issues. All tax treaties will generally contain articles that address:

- The counties affected (and what territory is included for purposes of each country); ${ }^{159}$

- The taxes to which the treaty applies; ${ }^{160}$

- Tie breaker rules for resolving residency conflicts; ${ }^{161}$

- Rules as to jurisdiction to tax certain types of receipt or income; ${ }^{162}$

- Rules as to who double taxation is to be eliminated; ${ }^{163}$

- Some contain rules that limit benefits of the tax treaty; ${ }^{164}$ and

- Various other rules. ${ }^{165}$

As with contracts and statutes, tax treaties will need to be interpreted before the articles can be given effect in particular circumstances. The interpretive exercise, however, is different than that for statutes. Given that treaties do not impose taxes themselves, represent an intergovernmental compromise of their tax jurisdiction, and represent a bargain as between the

Canadian and OECD work to counter treaty shopping. For example see Consultation Paper on Treaty Shopping The Problem and Possible Solutions (Department of Finance: Ottawa, ON, 2013), available online at http://www.fin.gc.ca/activty/consult/ts-cf-eng.asp. See also BEPS Action 6: Preventing the Granting of Treaty Benefits in Inappropriate Circumstances (OECD: Paris, France, 2014), available online at http://www.oecd.org/ctp/treaties/treaty-abuse-discussion-draft-march-2014.pdf.

${ }^{157}$ This can happen, for example, when a person is a resident of two countries and therefore is subject to taxation in both countries on their entire world-wide income. If a tax treaty exists between these two countries, it will provide residence tie-breaker rules that will seek to assign residency to one or the other country. For an example of the application of the tie-breaker rules see Black v The Queen, 2014 TCC 12, aff'd 2014 FCA 275. Summary available online at http://ita-annotated.ca/RecentDecisions/double-residents-effect-resident-tie-breaker-rules-tax-conventionsblack/.

${ }^{158}$ This will be achieved by facilitating with the administration of each country's tax legislation by allowing for the exchange of information (automatic or on request) between the tax authorities of each of the two countries. Although tax laws of one country are generally not enforced in another country, tax treaties may in some cases authorize one country to assist with the collection of another country's tax debt: see for example the Canada-US Tax Treaty, which in Article XXVI A provides for "Assistance in Collection" and in Article XXVII which provides for "Exchange of Information".

${ }^{159}$ In the OECD Model Treaty in Article 1

${ }^{160}$ In the OECD Model Treaty in Article 2.

${ }^{161}$ In the OECD Model Treaty in Articles 4 and 5.

${ }^{162}$ In the OECD Model Treaty in Articles 6-21 ("Taxation of Income") and Articles 22 ("Taxation of Capital").

${ }^{163}$ In the OECD Model Treaty in Articles 23A and 23B.

${ }^{164}$ Limitation of benefits provisions are not common in tax treaties. In the Canadian context, such a provision is only found in the Canada-US treaty, Article XXIX A, and limits the benefits in the treaty to "qualifying persons".

${ }^{165}$ For example, in the OECD Model Treaty: Article 3 covers "General Definitions"; Article 24 dealing with "nondiscrimination"; and Article 25 dealing with the "Mutual agreement procedure". 
countries for the benefit of their general societies, the interpretive exercise gives greater weights to the intention of the parties to the agreement.

Since tax treaties are treaties, their interpretation is governed by the Vienna Convention on the Law of Treaties. ${ }^{166}$ Specifically, Section 3 of that treaty, entitled "Interpretation of Treaties" provides a set of rules in Articles 31 to 33, that inform the interpretive exercise. Article 31 provides the general rules applicable when interpreting treaties, and highlights the importance of interpreting the treaty in good faith so as to obtain the ordinary meaning of the words used. ${ }^{167}$ In seeking to obtain the ordinary meaning, the words used must be considered in their context, and in light of the objects and purpose of the treaty and the provisions being interpreted. Article 32 provides guidance on the use of supplementary means of interpreting treaties so as to confirm the meaning obtained after applying the rules in Article $31 .^{168}$ Article 33 deals with interpretation of treaties authenticated in two or more languages. ${ }^{169}$

166 Vienna Convention on the Law of Treaties, Concluded on 23 May 1969, available online at https://reaties.un.org/doc/Publication/UNTS/Volume\%201155/volume-1155-I-18232-English.pdf.

${ }^{167}$ Article 31 reads:

1. A treaty shall be interpreted in good faith in accordance with the ordinary meaning to be given to the terms of the treaty in their context and in the light of its object and purpose.

2. The context for the purpose of the interpretation of a treaty shall comprise, in addition to the text, including its preamble and annexes:

(a) Any agreement relating to the treaty which was made between all the parties in connexion with the conclusion of the treaty;

(b) Any instrument which was made by one or more parties in connexion with the conclusion of the treaty and accepted by the other parties as an instrument related to the treaty.

3. There shall be taken into account, together with the context:

(a) Any subsequent agreement between the parties regarding the interpretation of the treaty or the application of its provisions;

(b) Any subsequent practice in the application of the treaty which establishes the agreement of the parties regarding its interpretation;

(c) Any relevant rules of international law applicable in the relations between the parties.

4. A special meaning shall be given to a term if it is established that the parties so intended.

${ }^{168}$ Article 32 reads:

Recourse may be had to supplementary means of interpretation, including the preparatory work of the treaty and the circumstances of its conclusion, in order to confirm the meaning resulting from the application of article 31 , or to determine the meaning when the interpretation according to article 31 :

(a) Leaves the meaning ambiguous or obscure; or

(b) Leads to a result which is manifestly absurd or unreasonable.

${ }^{169}$ Article 33 reads:

1. When a treaty has been authenticated in two or more languages, the text is equally authoritative in each language, unless the treaty provides or the parties agree that, in case of divergence, a particular text shall prevail.

2. A version of the treaty in a language other than one of those in which the text was authenticated shall be considered an authentic text only if the treaty so provides or the parties so agree.

3. The terms of the treaty are presumed to have the same meaning in each authentic text.

4. Except where a particular text prevails in accordance with paragraph 1, when a comparison of the authentic texts discloses a difference of meaning which the application of articles 31 and 32 does not remove, the meaning which best reconciles the texts, having regard to the object and purpose of the treaty, shall be adopted. 
When interpreting tax treaty provisions four general rules apply: ${ }^{170}$

- The interpretation rules in the Income Tax Conventions Interpretation Act ${ }^{171}$ must be applied;

- The treaty must be interpreted in good faith and in light of its objects and purpose ${ }^{172}$

- The paramount goal is finding the meaning of the words of the treaty by taking a liberal and purposive approach, looking a the language used, determining the intention of the parties, and using extrinsic materials to illustrate and illuminate the parties' intentions; ${ }^{173}$ and

- The interpretation of a treaty must be one that is functional, and therefore one where the whole scheme is considered in light of its intent, object, and spirit. ${ }^{174}$

The Canadian courts have often consulted the OECD Model Treaty ${ }^{175}$, particularly the commentaries to the various articles, so as to interpret similar wording used in Canadian tax treaties or so as to infer a meaning from omission of, or use of, certain words, phrases, and provisions. ${ }^{176}$ Note that the Canada-US Tax Treaty does not follow the OECD model, but it can be interpreted using the Technical Explanations ${ }^{177}$ published by the US Treasury Department. ${ }^{178}$

\subsection{Case Law}

\subsubsection{Overview}

Determining the appropriate and relevant statutory rules that are applicable to particular facts is not the end. The ITA (and other legislation) is written in general terms so as to cover a wide variety of foreseeable (and sometimes unforeseeable) occurrences. As such, most legislative provisions will require some form of interpretation to give them meaning in a

\footnotetext{
${ }^{170}$ For a good article dealing with the interpretation of tax treaties see John Pebble, "Interpretation of Double Tax Conventions" (1993) 78 International Tax Law 469, available online at http://ssrn.com/abstract=1582263.

${ }^{171}$ Organization for Economic Cooperation and Development, Model Tax Convention on Income and on Capital (OECD: Paris, France, 2014), condensed version available online at http://www.keepeek.com/Digital-AssetManagement/oecd/taxation/model-tax-convention-on-income-and-on-capital-condensed-version-2014_mtc_cond2014-en\#page1.

172 Vienna Convention on the Law of Treaties, United Nations Treaty Series (1980) Vol 1155, I-18232, available online at https://treaties.un.org/doc/Publication/UNTS/Volume\%201155/volume-1155-I-18232-English.pdf.

Article 31 provides the general rules for interpreting treaties, and Article 32 provides for the use of supplementary means when interpreting treaties.

${ }^{173}$ The Queen v Crown Forest Industries Limited et al, [1995] 2 SCR 802.

${ }^{174}$ Swathe v R, 1994 CarswellNat 1020 (FCA).

175 Organization for Economic Cooperation and Development, Model Tax Convention on Income and on Capital (OECD: Paris, France, 2014), condensed version available online at http://www.keepeek.com/Digital-AssetManagement/oecd/taxation/model-tax-convention-on-income-and-on-capital-condensed-version-2014 mtc cond2014-en\#page1.

${ }^{176}$ The Queen $v$ Crown Forest Industries Limited et al, [1995] 2 SCR 802.

177 For a copy of the US Model Income Tax Convention and Model Technical Explanations see http://www.irs.gov/Individuals/International-Taxpayers/The-U.S.-Model-Income-Tax-Convention-and-Model-

Technical-Explanation.

For the text of particular technical interpretations of the Canada-US Treaty see http://www.irs.gov/pub/irstrty/canatech.pdf and http://www.treasury.gov/resource-center/tax-policy/treaties/Documents/tecanada08.pdf .

${ }^{178}$ The Department of Finance has stated that the US Technical Interpretations of the Canada-US Tax Treaty accurately reflect Canada's position as to the interpretation of that treaty's provisions.
} 
particular context. Case law (judicial decisions) is a primary source of law that interprets legislative provisions. Where a court has settled a question within its jurisdiction and at issue in that case, ${ }^{179}$ then the court has done away with some sort of disagreement as to the interpretation and application of that particular provision. This decision can either be binding on other courts or can be persuasive, ${ }^{180}$ and in either case provides guidance for tax lawyers.

This portion of the paper will first set out the various courts whose decisions may have to be considered when trying to give meaning to tax legislation, and then provide guidance for reading, analyzing, and applying various courts' decisions.

\subsubsection{What Court(s) to Look at}

The jurisdiction over income tax matters, at first instance, is divided amongst the Tax Court of Canada ("TCC"), Federal Court - Trial Division ("FCTD"), and provincial superior courts. ${ }^{181}$ A researcher will need to know what court has jurisdiction over what matters so as to focous the research appropriately. ${ }^{182}$ This separation of jurisdictions, particularly as between the FCTD and the TCC has been criticized as making matters too complicated for taxpayers and their advisors.

The TCC has, since July 2003, been constituted as a superior court. This court deals with the correctness and propriety of the assessment, reassessment, or additional assessment of tax. Therefore where the issue involves a question as to the validity of an assessment, reassessment, or additional assessment, or a question of the admissibility of evidence to support an assessment,

\footnotetext{
${ }^{179}$ It is only matters at issue in a case that can give rise to binding precedent and identify the ratio of a case. The difference between ratio and obiter will be discussed later in the paper.

${ }^{180}$ Whether a decision or one court is binding or persuasive, whether it is applied or distinguished, will depend on the similarity of the particular facts of the two cases and the rules of stare decisis. For an explanation of the doctrine of stare decisis see the Federal Court of Appeal decision in Tuccaro v Canada, 2014 FCA 184, summarized online at http://ita-annotated.ca/RecentDecisions/res-judicata-stare-decisis-doctrines-explained/.

${ }^{181}$ When doing tax research, you have to keep in mind the evolution of the system used to settle tax disputes. What is currently the Tax Court of Canada, was not always so. Prior to the Tax Court of Canada we had:

- Income Tax Appeals Board, 1949 - 1959;

- $\quad$ Tax Appeal Review Board, 1958 - 1971;

- $\quad$ Tax Review Board, 1971 - 1983; and

- $\quad$ Appeals were to the Exchequer Court, 1917 - 1971, and then to the Federal Court - Trial Division, 1971 1983.
}

The Tax Court of Canada took over the jurisdiction over determining the correctness of tax liability from 1983 on. For General Procedure proceedings, appeals from decisions:

- Were to the Federal Court - Trial Division, 1983 - 1990; and

- $\quad$ Are to the Federal Court of Appeal, 1991 - current.

Note that the Tax Court of Canada has limited jurisdiction. The Federal Court - Trial Division, or Provincial superior courts may have jurisdiction over a particular matter, and therefore research will have to focous on those courts in particular circumstances.

The final court of appeal for Canada was to the UK Privy Council until 1949, after which the Supreme Court of Canada (established in 1875) the ultimate court of appeal in Canada.

For a more in-depth analysis of the history of Income Tax appeals see Colin Campbell, Administration of Income Tax 2013 (Carswell: Toronto, ON, 2013) at chapter 13.

${ }^{182}$ For a paper discussing the jurisdiction of the TCC to deal with Constitutional challenges, see David Jacyk, "The Jurisdiction of the Tax Court: A Tax Practitioner's Guide to the Jurisdictional Galaxy of Constitutional Challenges" (2012) 60:1 Canadian Tax Journal. 
or the law as to the adequacy of procedure in making an assessment, the TTC's decisions should be looked at. ${ }^{183}$ In addition to income tax matters, the TCC also deals with appeals respecting a number of other statutes. ${ }^{184}$ Specifically, the TCC has exclusive original jurisdiction to hear and determine, ${ }^{185}$ inter alia: ${ }^{186}$

- Appeals and references with respect to matters arising under the ITA, Canada Pension Plan, ${ }^{187}$ Employment Insurance Act ${ }^{188}$ Part IX of Excise Tax Act, ${ }^{189}$ Old Age Security Act, ${ }^{190}$ and Petroleum and Gas Revenue Tax Act ${ }^{191}$, Softwood Lumber Products Export Charge Act, ${ }^{192}$ Cultural Property Export and Import Act, ${ }^{193}$ Customs Act, ${ }^{194}$ Investment Canada Act, ${ }^{195}$ and Air Travelers Security Charge Act ${ }^{196} ;{ }^{197}$

- Determination of questions of law or mixed fact and law referred to the TCC pursuant to ITA, sections 173 or 174, and Excise Tax Act, ${ }^{198}$ sections 310 or 311 ;

- Appeals with respect to matters arising under the War Veterans Allowance Act, ${ }^{199}$ and Civilian War-Related Benefits Act $^{200} ;^{201}$ and

- Applications to extend time to file an objection or appeal under the ITA or the Excise Tax Act. $^{202}$

The FCTD has jurisdiction to hear and determine judicial review applications that challenge a decision by the Minister or his/her delegates. This is because the Minister is a "federal board, commission or other tribunal", and the FCTD has wide powers and exclusive

${ }^{183}$ See Canada (National Revenue) v JP Morgan Asset Management (Canada) Inc, 2013 FCA 250.

${ }^{184}$ For example the Canada Pension Plan, , and the Employment Insurance Act, .

${ }^{185}$ Note that the ITA limits the remedies that can be granted by the TCC on appeal. For example, subsection $169(1)$ allows the TCC to vary or vacate the assessment. Specifically, section 171, in subsection 171(1) allows the TCC to dispose of an appeal by:

(a) dismissing it; or

(b) allowing it and

(i) vacating the assessment,

(ii) varying the assessment, or

(iii) referring the assessment back to the Minister for reconsideration and reassessment.

${ }^{186}$ Tax Court of Canada Act, RSC 1985 c T-5, section 12.

${ }^{187}$ RSC 1985, c C-8.

${ }^{188} \mathrm{SC} 1996$, c 23.

189 RSC 1985, c E-15. The rules of practice and procedure for these appeals from the Excise Tax Act (and other legislation) are at times separate and distinct from those applicable to appeals under the ITA. However, the TCC is in the process of producing a unified and single set of rules of practice and procedure for all appeals over which it has jurisdiction.

${ }^{190}$ RSC 1985, c O-9.

${ }^{191} \mathrm{RSC} 1985$, c P-12.

${ }^{192} \mathrm{SC} 2006, \mathrm{c} 13$.

${ }^{193}$ RSC 1985, c C-51.

${ }^{194}$ RSC 1985, c 1 (5th Supp).

${ }^{195}$ RSC 1985, C 28 (1st Supp).

${ }^{196}$ SC 2002, c 9 .

${ }^{197}$ Where those acts generally or specifically provide for appeals to the TCC.

${ }^{198}$ RSC 1985, c E-15.

${ }^{199}$ RSC 1985 , c W-3.

${ }^{200}$ RSC 1985, c C-31.

${ }^{201}$ See Veterans Review and Appeal Board Act, SC 1995, c 18, Section 33, provides that any questions as to source of income or income shall lie with the TCC.

${ }^{202}$ RSC 1985, c E-15. 
jurisdiction with respect of judicial review of the Minister's decisions. ${ }^{203}$ For example, where the ITA grants the Minister a discretionary power, the exercise or failure to exercise that power may be challenged by applying or judicial review by the FCTD. However, for such an application to lie: ${ }^{204}$

- The claim must be a cognizable administrative law claim, not a disguised or collateral attach on an assessment, reassessment, or additional assessment (or other matter falling within the jurisdiction of the TCC or another court);

- The FC must not be prevented with dealing with the claim because of Federal Courts $A c t,{ }^{205}$ section 18.5 (where jurisdiction has been granted to another court) or another rule of law (other remedies available but not sought); and

- The FC must be able to grant the relief sought.

In addition to hearing judicial review applications challenging the Minister's exercise of power, the FCTD has jurisdiction with respect to:

- Certification of corporate liabilities as part of a Director's liability assessment; ${ }^{206}$ and

- Certification of amounts payable under the ITA. ${ }^{207}$

The ITA expressly grants power in relation to certain matters to particular courts. The FCTD and provincial superior courts have jurisdiction under the ITA to:

- Grant and review collection action under the collection and jeopardy provisions; ${ }^{208}$

- Authorize the entry of a dwelling place; ${ }^{209}$

- Authorize the disclosure of Third-Party information; ${ }^{210}$ and

- Determination of claims of solicitor-client privilege. ${ }^{211}$

The FCA has jurisdiction under the ITA to:

- Determine appeals from notices of revocation of Registered Education Savings Plans, ${ }^{212}$

- Determination of appeals from notices of revocation of Registered Pension Plans, ${ }^{213}$ and

- Determination of appeals from notices of revocation of a Registered Charity or a Registered Canadian Amateur Athletic Association. ${ }^{214}$

\footnotetext{
${ }^{203}$ Federal Courts Act, RSC 1985, c F-7, sections 18 and 18.1.

${ }^{204}$ See Canada (National Revenue) v JP Morgan Asset Management (Canada) Inc, 2013 FCA 250.

${ }^{205}$ RSC 1985, c F-17.

${ }^{206}$ ITA s 227.1; and Excise Tax Act s 323.

${ }^{207}$ ITA s 223.

${ }^{208}$ ITA s 225.2.

${ }^{209}$ ITA s 231.1.

${ }^{210}$ ITA s 231.2.

${ }^{211}$ ITA s 232.

212 ITA s 146.1.

${ }^{213}$ ITA s 147.1.

${ }^{214}$ ITA s 168.
} 
Finally, the FCTD and provincial superior courts have jurisdiction to hear matters, within their respective jurisdictions, to hear matters relating to:

- Breach of contract claims;

- Tort claims (regulatory negligence, negligent misrepresentation, fraud, abuse of process, or misfeasance in public office $)^{215}$; and

- Criminal law matters.

The above partial listing of courts and jurisdictions is meant to cover tax cases only. However, as stated earlier, the ITA functions against the backdrop of the common law and other statutes (and cases interpreting those statutes) that make up the legal landscape. These non-tax cases may need to be understood to appreciate the tax consequences of the facts before the researcher.

\subsubsection{Reading Court Decisions}

The purpose of reading court's decision is not only to understand what the law is (or was at a particular point in time), but also to predict how a court may decide a future case given particular facts. Making predictions based on past cases is a special skill that requires the researcher to identify the legal principles found in a case and understand the rules that determine if and to what extent another court must follow the same principles. ${ }^{216}$ Whether a subsequent court is bound by another court's decision or not, and whether the other court's decision is persuasive or not, depends on the level and jurisdiction of the courts involved, the facts of the cases being compared, and the matters at issue in a case being relied on.

In reading court decisions, the researcher will notice that there is a difference between the decisions of courts of first instance and the decisions of courts of appeal. The decisions of courts of first instance tend to focous more on the evidence and the facts as it is the responsibility of these courts to find the facts to which the law will be applied. The decisions of courts of appeal will tend to focous more on the law and give deference to the trail court's findings of facts (absent a palpable and overriding error). This is because the role of courts of appeal is to determine questions of law, and they are not well positioned to make findings of fact as they do not hear witness testimony. Also, decisions of courts of appeal tend to be longer, as they tend to review and analyze the legal issues in more detail so as to provide guidance for lower courts.

Reading, analyzing, and applying court decisions as part of legal research is not an easy task. The skills required to make use of court decisions are honed through practice and experience. However, there are some guidelines and rules that can help get the researcher started on the path. A researcher will need to understand, inter alia: the difference between the

\footnotetext{
${ }^{215}$ See Canada (National Revenue) v JP Morgan Asset Management (Canada) Inc, 2013 FCA 250.

${ }^{216}$ A good litigator also understands the importance of understanding the particular judge one will argue in front, as well as have developed the skills that make a person a persuasive presenter of information. Many books have been written on the topic of advocacy, including: David W Chodikoff, Advocacy and Taxation in Canada (Irvin Law: Toronto, 2004); Geoffrey Adair, On Trial: Advocacy Skills Law \& Practice, 2nd ed (Butterworths Canada; Toronto, 2004); Gerry Spence, Win your case: How to present, Persuade, and Prevail - Every Place, Every Time (Martin's Press, 2006); Irving Younger, The Irving Younger Collection": Wisdom \& Wit from the Master of Trial Advocacy (American Bar Association, 2011).
} 
decisions of trial courts/courts of first instance and the decisions of appeal courts; the difference between binding decisions and persuasive decisions; the operation of stare decisis; and the difference between obiter and ratio in decisions. This is part art and part science.

The first task is knowing what types of information can be found in a judgment. Court decisions (judgments), either explicitly or implicitly, will present the following information:

- $\quad$ Style of Cause, ${ }^{217}$

- Judge(s) rendering the decision(s); ${ }^{218}$

- Headnotes; ${ }^{219}$

- Counsel; ${ }^{220}$

- Procedural History; ${ }^{221}$

- Facts; $^{222}$

- Issues; ${ }^{223}$

- Argument(s); ${ }^{224}$

- Analysis (decision proper) ${ }^{225}$

- Conclusion; and ${ }^{226}$

- Costs. $^{227}$

It is also important to understand the relationship of the various courts to one another. Canadian courts are arranged hieratically. ${ }^{228}$ For tax matters, the TCC and the FCTD are the lowest level of court, followed by the FCA, and sitting at the apex is the Supreme Court of

${ }^{217}$ Also known as the case name, this is the formal name the case is referred to by, indexed as, and cited using. The manner of presenting the style of cause is determined by the identity of the parties and the applicable rules of court.

${ }^{218}$ At the TCC and the FCTD, there will only be one judge who will hear and render a decision. At the Federal Court of Appeal and the Supreme Court of Canada, a panel of judges will render a decision.

${ }^{219}$ Headnotes are not part of the court's judgment, but rather is a summary and interpretation of the decision by a legal writer. They cannot be relied on as law.

${ }^{220}$ The lawyer(s) representing the Crown and the taxpayer are named in the decision. You will find that decisions at the TCC and the FCTD often will identify the appellant as representing himself/herself. Unrepresented litigants have increased at all levels of court.

${ }^{221}$ This is a recounting of the steps taken prior to the matter coming before the court rendering the decision.

${ }^{222}$ This may include an agreed statement of facts as well as the uncontroversial facts established during the hearing. This portion may also include legally irrelevant facts that provide the social and historical context of the case.

${ }^{223}$ Courts will often identify the issues that they must decide in rendering a decision. This may be presented either in the body of a paragraph or, as is becoming increasingly common, in point form.

${ }^{224}$ This is where the arguments advanced by each side are summarized by the court.

${ }^{225}$ This is the portion of the judgment where the court will identify the law, settle factual controversies (by making findings of fact), and settle any controversial legal questions.

${ }^{226}$ Most courts will provide a brief summary of the substance of the decision.

${ }^{227}$ At or near the end of the decision, the court will refer to courts. Often the court will award cost to the winning party, thereby requiring the losing party to cover some or all of the winning party's legal costs and disbursements. How much, and how, such costs awards are determined, and what factors are considered, is beyond the scope of this paper. For a good summary for the TCC see Spruce Credit Union v The Queen, 2014 TCC 42, summary available online at http://ita-annotated.ca/RecentDecisions/fixed-cost-awards-tax-court-canada-spruce-credit/.

228 The structure of Canada's court system is described on the SCC website at http://www.scc-csc.gc.ca/courtcour/sys-eng.aspx.

Note that because of the interaction of the federal nature of the ITA with Québec's Civil Law system, federal tax cases must be considered carefully so as to determine whether the outcome is dependent on or independent from the Civil Code of Quebec. 
Canada ("SCC"). ${ }^{229}$ Through the operation of the principles of stare decisis, lower courts are required to follow - are bound by - the decisions of higher courts. ${ }^{230}$ This means that the TCC or the FCTD is bound ${ }^{231}$ by a decision of the FCA or the SCC, and the FCA is bound by a decision of the SCC. ${ }^{232}$ However, the decisions of provincial or territorial courts of appeal are not biding on the TCC, FCTD, or the FCA, though they may be persuasive. ${ }^{233}$ Similarly, decisions by the same level of court (by different judges of the same court) are not binding, they are merely persuasive. ${ }^{234}$ Finally, decisions rendered by courts in response to a reference question are not binding but merely persuasive.

However, just because a higher court has made a decision in one case that involves similar facts and the operation of the same provision(s) does not mean that a lower court is automatically bound by the higher court's decision. Where the lower court makes findings of fact that are different than that in the higher court decision and determines that those facts are significant facts, or where the applicable law is different or has changed since the higher court decision was rendered, the lower court may distinguish the higher court decision. By distinguishing the higher court decision, the lower court is freed to come to its own conclusions. $^{235}$ This is because, in the common law tradition, courts make decisions in a case based on the particular facts of that case. Although a court may make a statement as to the law that appears to be one of general application, this may be nothing more than a solid starting point from which a researcher (and another court) begins his/her analysis. The goal, in each case, is to

\footnotetext{
${ }^{229}$ For a summary of the history of the court hierarchy in relation to tax matters, see supra note 118 .

${ }^{230}$ For an explanation of the doctrine of stare decisis see the Federal Court of Appeal decision in Tuccaro v Canada, 2014 FCA 184, summarized online at http://ita-annotated.ca/RecentDecisions/res-judicata-stare-decisis-doctrinesexplained/.

${ }^{231}$ Where the facts before the court are the same as (on all fours as) the facts before the higher court, the lower court must follow the same reasoning as the higher court and the outcome of the case must be the same as under the higher court.

${ }^{232}$ For tax cases, other than criminal tax cases, there is no automatic right of appeal to the SCC. Rather, a party wishing to appeal a FCA decision to the SCC must apply for leave to appeal. The SCC will only grant leave to appeal where the court considers that the issue is one of national importance.

Note that courts of appeal can hear appeals with a differing number of judges sitting on a panel. The FCA may hear a case sitting either as a panel of 3 judges or a panel of 5 judges. The SCC may hear a case sitting either as a panel of 5, 7, or 9 judges. Generally, for a court to overturn its own decision, this will have to be done by a panel of judges that consists of more judges than rendered the impugned decision.

${ }^{233}$ When a decision is persuasive, and the extent to which it is persuasive, may sway the court to come to a similar or the same decision as the other court did. The closer a case is in facts and law to the particular case before a judge, the more persuasive the other decision will be. Judges will often refer to the principle of "judicial comity", and whenever possible attempt to reach the same conclusion as other courts have reached in substantially similar cases in substantially similar circumstances. The more judges of a particular court have reached a particular disposition in a matter, the more likely it is that other judges of that court will also approach a case in the same way. This practice of judges of a level of court following decisions of other judges at that level also promotes certainty and predictability of the law whenever possible.

The persuasiveness of a decision is affected by its age (more recent decisions are more reflective of the current thinking of the court and its judges and are more likely to persuade them), and how it has been judicially considered (a decision that has been approved of and followed by other courts is more persuasive than one that has been distinguished, not followed, or questioned by other courts).

${ }^{234}$ Cases decided under the Informal Procedure of the TCC have no precedential value. Only those under the General Procedure have some precedential value.

${ }^{235}$ For a good example of how lower courts may distinguish a case, even when the issues are significantly the same, see the British Colombia Supreme Court decision in Carter v Canada (AG), 2012 BCSC 1587, and the British Colombia Court of Appeal's overturning of that decision in 2013 BCCA 435.
} 
render a decision that is right and just given the law at the time the matter comes before a court and based on the fact proved in that case.

It is also important to distinguish between the obiter dicta ${ }^{236}$ of a decision and its ratio decidendi. ${ }^{237}$ The ratio of a higher court is binding on a lower court, but the dicta of a higher court is not binding of a lower. ${ }^{238}$ Differentiating between ratio and obiter can be difficult, often requiring a careful reading and deep understanding of the case. This analysis is further complicated when the higher court decision is a split decision with one or more concurring decisions $^{239}$ and dissenting decisions ${ }^{240}$, and especially when the split is not the same as among all of the issues before the court. ${ }^{241}$

After the researcher has determined what cases are binding and which are persuasive, has distilled the relevant facts for each decision, and sifted ratio from obiter, s/he still has to apply this knowledge to the facts and circumstances of a particular client. The more uncertain a particular area is, the more difficult this task becomes. The researcher must reason by analogy and determine what portions of the client's facts are similar to or different from the previously decided case, whether these differences are significant, and what the outcome may be given these differences. Successful prediction is a matter of judgment developed through experience.

Finally, it is important for the researcher to assure himself/herself that the wording of the provisions (and the state of the common law, where applicable) is the same now as when the previous decisions were rendered, and that the decision relied on has not been appealed. The ITA is amended often, and it may well be that the wording supporting a decision has been amended such that the reasoning in that old decision is not longer sound. A decision may also have been appealed or may be under appeal. The soundness of the reasoning of a decision may be undermined if that decision is overturned on appeal, and caution must be exercised when an important decision is under appeal. ${ }^{242}$

\footnotetext{
${ }^{236}$ Obiter dicta (called obiter for short) are "comments made as an aside" by a judge, and are in reference to matters not at issue in the particular case, or matters that need not be decided to render a decision in a particular case.

${ }^{237}$ Ratio decidendi (called ratio for short) are "reasons for the decision" by the judge, and address the matters at issue in a case, and are matters that must be decided in order for the court to be able to render a decision.

${ }^{238}$ Obiters of higher court decisions are often very persuasive because such comments hint at the thinking of the higher court, and indicate how those judges may decide a case on appeal.

${ }^{239}$ A concurring decision is one or more judges agreeing with the outcome of the case as determined by the majority decision, but differing as to the law leading to the result.

${ }^{240}$ A dissenting decision is one or more judges disagreeing with the outcome, whether or not they agree or disagree as to the law leading to the outcome.

${ }^{241}$ Also note that the fact that courts of appeal are composed of panels consisting of varing number of judges may affect the persuasive weight to be given to decisions. The obiter of a SCC decision rendered by a panel of 5 judges will not be as persuasive as one rendered by a panel of 9 judges, and the obiter in split decisions will not be as persuasive as the obiter in unanimous decisions.

${ }^{242}$ Note that a tax appeal does not get to the Supreme Court of Canada as of right. The person seeking to appeal has to apply for leave to appeal. The SCC may or may not grant an application for leave to appeal. The failure to grant leave does not mean that the SCC agrees with the reasoning of the court below, but only that the SCC has determined that the case does not meet the standards necessary to be heard by the SCC (for example, the matter is not one of national interest).
} 


\section{Secondary Sources of Tax Law}

\subsection{Overview}

Secondary sources of law are not "law", but rather are interpretations, comments, history, and analysis of law. Such sources include government publications, legislative debates, scholarly papers, textbooks, articles, and commercial commentary and analysis. They provide an overview of the law, some commentary and historical development, reference to leading cases, often provide the researcher with a list of related provisions, and listings of other relevant secondary sources. This makes secondary sources a good starting point for legal research. However, a researcher should always consider the date on which a secondary source was published/prepared, and understand that such sources are often not up to date.

\subsection{Non-Government Secondary Sources}

There are a large number of Canadian and international secondary sources of tax law. These materials may be prepared either for practitioners (accountants or lawyers), academics, taxpayers, or students (or for a combination of these persons). For tax law, the most commonly referred to secondary sources are:

- Tax textbooks; ${ }^{243}$

- Tax scholarly papers; ${ }^{244}$

- International Financial Reporting Standards ${ }^{245}$ and related documents, and the Canadian Chartered Professional Accountants Manual;

- Tax Professional Publications and Guides (eg. Looseleaf services, annotated acts, etc.); and

- Organization for Economic Cooperation and Development, Model Tax Treaty and its commentary. ${ }^{246}$

It is a good idea for a researcher to being by looking at a reputable secondary source so as to get a general understanding of the law. A good secondary source will also point the researcher towards related provisions, related statutes, and leading cases. This can save the researcher time and effort. However, each type of secondary source has its uses, focous, and limitations. For example, textbooks tend to provide general, academically focoused, reviews of the law, and they

\footnotetext{
${ }^{243}$ There are many Canadian textbooks that deal with domestic income taxation generally. There are also a great many textbooks and treatises that deal with particular and specialized areas of tax law.

${ }^{244}$ Two great sources for tax-related scholarly papers are http://ssrn.com and http://ctf.ca (which also contains a large volume of practitioner related materials).

Other organizations that provide secondary resources include: Tax Executives Institute, Chartered Professional Accountants (CPA) Canada, CPA Tax Policy Committee, CPA Commodity Tax Committee, Joint Committee on Taxation of the CBA and CPA, and the International Fiscal Association.

${ }^{245}$ These are designated as the common international accounting language that allows company accounts to be understandable and comparable across international boundaries. The standards are set and modified by the International Accounting Standards Broad. For more information see http://ifrs.org.

${ }^{246}$ Organization for Economic Cooperation and Development, Model Tax Convention on Income and on Capital (OECD: Paris, France, 2014), condensed version available online at http://www.keepeek.com/Digital-AssetManagement/oecd/taxation/model-tax-convention-on-income-and-on-capital-condensed-version-2014 mtc cond2014-en\#page1.
} 
also tend to be updated less frequently. Scholarly papers, on the other hand, tend to focous on narrow areas of the law, and provide fairly detailed commentary and criticism of that particular area. A researcher should consult a variety of secondary sources so as to get as complete an overview as possible.

\subsection{Government Secondary Sources}

Government publications of interest to the income tax researcher can be those either from the Department of Finance ${ }^{247}$ or the Canada Revenue Agency ("CRA"). ${ }^{248}$ Because of the volume and complexity of tax law, tax lawyers, accountants, and the public make frequent use of government publications so as to understand the law. ${ }^{249}$ The most often referred to source of government documents for income tax purposes are publications by the Canada Revenue Agency. ${ }^{250}$ These CRA's publications include: ${ }^{.251}$

- Income Tax Folios: these are replacing the Interpretation Bulletins and Income Tax Technical News, and present the CRA's interpretation of the law; ${ }^{252}$

- Income Tax Information Circulars: expressions of the CRA's procedures, policies, and assessment practices; ${ }^{253}$

- Income Tax Interpretation Bulletins: expressions of the CRA's opinion as to the interpretation of the ITA; ${ }^{254}$

\footnotetext{
${ }^{247}$ The Department of Finance is responsible for drafting new tax law and amendments to tax law. When bills are introduced to Parliament they are often accompanied by explanatory notes (called technical notes) that set out the purpose of the draft legislation. The technical notes generally set out what the law was prior to the change proposed in the draft, why the change is being made, and what the effects of the proposed change will be. This is not determinative, and one must be alive to the amendments made to a bill during the legislative process.

Other important Department of Finance publications are the federal Budget papers (consisting of the budget speech, the supplementary information, and the Notice of Ways and Means Motions), press releases announcing upcoming changes, Regularity Impact Analysis Statements (explaining the purpose behind changes in regulations), various policy papers, Economic and Fiscal Updates, Fiscal Monitor, Tax Expenditure Reports, Debt management Reports, Debt Management Strategies, Annual Financial Reports of the Government of Canada, Fiscal Reference Tables, and comfort letters (confirming the intention of the department to recommend changes to the ITA in particular ways). Department of Finance publications are available online at http://www.fin.gc.ca.

${ }^{248}$ The Canada Revenue Agency is takes with the administration and the enforcement of the ITA (and a number of other statutes).

${ }^{249}$ Note that courts in Canada have consistently held that such government publications are not the law and are not binding even on the government or agency that publishes the document, though there are limited uses for such guidelines: Therrien $v$ The Queen, 2004 TCC 791. For an analysis of the legal effect of guidelines see Lorne Sossin and Sas Ansari, "Legitimate Expectations, soft law and tax administration" (Forthcoming).

${ }^{250}$ The Canada Revenue Agency ("CRA") publications are generally available online at http://www.cra.gc.ca. Some publications are only available through Access to Information Act requests through commercial publishers.

251 For links to websites containing these publications go to http://ita-annotated.ca/RecentDecisions/taxresearch/sources-of-information/government-publications/.

Other CRA publications include: Canada Pension Plan Rulings, Employment Insurance Rulings, GST/HST Rulings and interpretations, CRA fact sheets, and tax tips.

252 Income tax folios are organized into broad categories, and can be found online at http://www.craarc.gc.ca/tx/tchncl/ncmtx/ntrfls-eng.html.

${ }^{253}$ Archived Information Circulars can be found online at http://www.cra-arc.gc.ca/menu/ICSC-e.html.

${ }^{254}$ Archived Interpretation Bulletins can be found online at http://www.cra-arc.gc.ca/menu/ITSC-eng.html.
} 
- Income Tax Technical Interpretations and other Interpretations: produced by the CRA's Rulings Directorate, that set out the CRA's interpretation of particular provisions (available through commercial services);

- Income Tax Technical News: Announce changes to interpretative positions or administrative policy, practice, or procedures, ${ }^{255}$

- Sector Publications: publications targeted to particular sectors (eg Charities and nonprofit organizations;

- Advanced Income Tax Rulings: the CRA's assessment of the tax consequences of a transaction or proposed transaction, on specific facts, issued on the request (and at the expense) of a taxpayer;

- Application Policies: Dealing with the Scientific Research and Experimental Development tax credit;

- CRA Appeals Manual: An internal guide for CRA employees that are tasked with determining appeals;

- CRA Audit Manual: An internal guide for CRA employees that are tasked with conducting audits;

- Tax Forms: forms that are issued because they are "prescribed" have the force of law, while other forms do not; ${ }^{256}$

- Tax Guides: Non-technical information for use by the general public; ${ }^{257}$

- CRA Pamphlets: non-technical publications that deal with particular income tax matters; ${ }^{258}$

- News Releases: Generally inform the public about changes in the CRA's administration of the ITA; and

- Various Rates (Income Tax Rates, Prescribed Rates, etc)

CRA and other government publications are not law and do not have the force of law. ${ }^{259}$ Taxpayers are not able to rely on these publications and pronouncements, and the government is generally not estopped from acting contrary to these declared views in such publications and pronouncements. ${ }^{260}$ This inability to rely on the CRA statements is not limited to publications and pronouncements to the general public, but also extend to express promises or views expressed to particular taxpayers in advance tax rulings (despite the CRA's position and consistent practice of regarding such rulings as binding). ${ }^{261}$ One thing these documents do provide is the position that the tax authority is likely to take. As such, if the researcher's goal is

\footnotetext{
255 Archived Income Tax Technical News can be found online at http://www.cra-arc.gc.ca/tx/tchncl/ncmtx/tnws3eng.html.

${ }^{256}$ Tax Forms can be found online at http://www.cra-arc.gc.ca/menu/TFTF-e.html.

${ }^{257}$ Tax Guides cab be found online at http://www.cra-arc.gc.ca/menu/TGTG-e.html.

${ }^{258}$ Tax Pamphlets can be found online at http://www.cra-arc.gc.ca/menu/TGTG-e.html.

259 See Harel $v$ The Deputy Minister of Revenue in the Province of Quebec, [1978] 1 SCR 851; see also $R v$ Nowegijick, [1983] SCJ o 5, 83 DTC 5041 (SCC).

${ }^{260}$ See Stickel $v$ MNR, [1972]] FCJ no 53, rev'd on other ground by FCA in 72 DTC 6178 (FCA), subsequently affirmed by SCC in 74 DTC 6269 (SCC); see also MNR v Inland Industries, [1971] SCJ No 145. More recently, see the Federal Court decision in Teletech Canada v. MNR (2013) http://www.oba.org/Sections/TaxationLaw/Articles/Articles-2013/October-2013/TeleTech-Canada,-Inc-v-Minister-of-National-Revenue.

${ }^{261}$ See Woon v MNR, [1950] CTC 263 (Ex Ct). I have not encountered any recent decisions in respect to such rulings, likely because the CRA's administrative practice.
} 
to reduce risk, knowing what the CRA will likely do (whether this is right in law or not) may be more important than the correct state of the law.

However, these publications and pronouncements can have legal effect and are given weight, thereby becoming potentially important factors with legal effect, when there is doubt as to the meaning of legislation, ${ }^{262}$ when stopple is an issue, or where the issue is one of proper procedure. $^{263}$ The remedies available on the basis of government publications and pronouncements can be purely procedural, or they may be substantive in nature, and the use that can be made of such publications will differ depending on what court the proceedings are before. For example, the TCC will give little weight to the conduct of the Minister, but will give some weight to government publications in interpreting ambiguous/unclear provisions or to statements of fact made by the Minister. The FCTD, on the other hand, will care little about the effect of government publication and pronouncements that affect the correctness of the (re)assessment, but may give weight to materials that relate to the Minister's conduct in rendering that (re)assessment.

The FCTD, on judicial review, will consider the conduct of the Minister and compare this to publications and pronouncements as to Ministerial conduct. The court, after review, may grant procedural remedies. Procedural remedies are imported by the doctrine of Legitimate Expectations as part of the rules of natural justice and procedural fairness, and they may: ${ }^{264}$

- extend procedural protections beyond what the circumstances may otherwise require, ${ }^{265}$ and

- may determine what procedures the duty of fairness requires in any circumstances. ${ }^{266}$

Therefore, the conduct, publications, and statements of the administrative decision-maker are useful to the court as an indicator of fairness on the basis of the expert administrator's view of what constitutes fair procedure in the circumstances. ${ }^{267}$

The TCC is tasked with determining whether the (re)assessment by the Minister is correct in law. When doing so, the TCC will make use of governmental publications and pronouncements. However, the CRA and other government bodies are not legislative and cannot change the law. Therefore, they cannot change or override a clear expression of law through administrative practice, pronouncement, or publication. Where the legislation is ambiguous,

${ }^{262}$ See Harel $v$ The Deputy Minister of Revenue in the Province of Quebec, [1978] 1 SCR 851; see also $R v$ Nowegijick, [1983] SCJ o 5, 83 DTC 5041 (SCC).

${ }^{263}$ Within bounds of fairness.

${ }^{264}$ Old st Boniface Residents Assn Inc v Winnipeg (City), [1990] 2 SRC 1170; Reference Re Canada Assistance Plan (BC), [1991] 2 SCR 525; CUPE v Ontario (Minister of Labour), 2003 SCC 29; Agriria v Canada, 2013 SCC 36.

${ }^{265}$ Old st Boniface Residents Assn Inc v Winnipeg (City), [1990] 2 SRC 1170; Reference Re Canada Assistance Plan (BC), [1991] 2 SCR 525; CUPE v Ontario (Minister of Labour), 2003 SCC 29; Agriria v Canada, 2013 SCC 36.

${ }^{266}$ Baker v Canada (Minister of Citizenship and Immigration), [1999] 2 SEC 817.

${ }^{267}$ Martineau v Matsqui Disciplinary Bd, [1980] 1 SCR 603. The courts will respect the procedure adopted by administrative agencies to some extent. So long as the procedures fall within a range of fair procedure, the courts will allow the administrative agency to choose its own procedure, thereby employing its experience as to what constitutes fair procedure in the circumstances. See also Baker v Canada (Minister of Citizenship and Immigration), [1999] 2 SEC 817. 
then the interpretation bulletins and other similar CRA statements carry real weight. ${ }^{268}$ Nevertheless, courts have refused to simply rely on administrative practice when provisions are unclear. $^{269}$ Where the policy contradicts the wording of the provision or, without contradicting the wording of the provision, the position is not supported by the legislation, the policy can be of no help. ${ }^{270}$ Specifically, government publications and pronouncements may:

- be used by courts to determine the implied interpretation of words, phrases, or criteria employed by a decision-maker as part of an analysis of the reasonableness of the interpretation; ${ }^{271}$ and

- be used in interpreting statutory provisions as administrative guidelines are part of the broader context of the statute, ${ }^{272}$ and may help the court to identify the purpose of a provision. $^{273}$

Finally, as part of the court's application of the proper standard of review, on judicial review before the FCTD, government publications and pronouncements may through the operation of the doctrine of Legitimate Expectations:

- be a useful indicator of what constitutes a reasonable interpretation of the power conferred on the decision-maker; ${ }^{274}$

- be useful in determining whether the decision rendered by the decision-maker is reasonable or not; ${ }^{275}$ and

- help determine what the criteria relevant in the exercise of discretion are. ${ }^{276}$ However, whatever the role of guidelines in setting out relevant considerations, the weight to be assigned to the relevant factors and the weighting of competing factors is, so long as within a range of reasonable decisions, for the decision-maker. ${ }^{277}$

\footnotetext{
${ }^{268}$ See Harel, where the SCC referred to the decisions in The Commissioners for Special Purposes of the Income Tax v Pemsel, [1891] AC 531; Protestant Old Ladies' Home v Provincial treasurer of Prince Edward Island, (1941) 2 DLR 534, to support its position.

${ }^{269}$ The TCC in Brelco (Brelco Drilling Ltd.v. The Queen, 98 DTC 1422 (T.C.C.) at p 430, reversed on other ground, stated that conforming to administrative practice so as to enhance equity among taxpayers is not appropriate, and taxpayers "should not feel obliged, because it is expedient, to observe administrative edicts when the law is simply lacking in clarity".

${ }^{270}$ Wollenberg $v$ MNR, 84 DTC 1055 (TCC). This is linked to doctrine of fettering of discretion by an administrative decision-maker.

${ }^{271}$ Agriria v Canada, 2013 SCC 36. Reasonableness of an interpretation will look to the plain words, legislative history, evident purpose, and statutory context of the words, phrases, or criteria.

${ }^{272}$ Agriria v Canada, 2013 SCC 36.

${ }^{273}$ Department of Finance explanatory notes are used by the court to determine the purpose or intention of parliament in enacting a provision or making a particular amendment, therefore playing a role in the application of the modern rule of statutory interpretation.

${ }^{274}$ Baker v Canada (Minister of Citizenship and Immigration), [1999] 2 SEC 817; Agriria v Canada, 2013 SCC 36.

${ }^{275}$ Baker v Canada (Minister of Citizenship and Immigration), [1999] 2 SEC 817; Agriria v Canada, 2013 SCC 36.

${ }^{276}$ CUPE v Ontario (Minister of Labour), 2003 SCC 29, dissenting judgment. The court in CUPE stated that the LE as to reasonable criteria may arise from legislation, regulations, international conventions, or guidelines. The SCC in Agriria v Canada, 2013 SCC 36, provided more guidance, and said that criteria stated to be relevant in guidelines give rise to a LE that they will be considered, such that they must be considered, where the guidelines are a relatively comprehensive code in respect of the decision or exercise of discretion.

${ }^{277}$ Canada v Telfer, 2009 FCA 23.
} 
The latter two lists demonstrate the substantive effect that government publications and pronouncements may have.

For example, in the voluntary disclosure program ${ }^{278}$ context, several cases have held the Minister to the conditions and relief set out in the relevant Information Circular. ${ }^{279}$ In Karia $^{280}$ which was never appealed, the Federal Court held that although the Information Circulars are not delegated legislation and have no force of law "as such", ${ }^{281}$ promissory estoppel would operate to prevent the Minister to exercise discretion contrary to the promise contained in the Information Circular (so long as the Minister has the necessary lawful authority). ${ }^{282}$ But, where the requirements for estoppel are not met, the Federal Court has held that Information Circulars are not binding on the Minister in the exercise of the Minister's discretion. ${ }^{283}$ Outside of the estoppel context, guidelines have been held to be relevant in assessing the reasonableness of the Minister's decision, and may therefore reduce the range of reasonable alternatives. ${ }^{284}$

Note that these publications and pronouncements will often be relied on by courts when they favour the taxpayer and the taxpayer has consulted and relied on them, ${ }^{285}$ but not when they favour the government who drafted them. ${ }^{286}$

\footnotetext{
${ }^{278}$ The voluntary disclosure program uses the discretion of the Minister to waive interest and penalties.

279 Recently, the FCA in Sifto had to determine whether a taxpayer's argument had no reasonable prospect of success. The taxpayer argued that once accepted by a Minister as meeting the voluntary disclosure as meeting the conditions of the program as set out in the information circular, the Minister was bound to waive the interest and penalties applicable. In discussing remedies, the FCA stated that "the Federal Court may grant a declaration based on administrative law principles that the Minister acted unreasonably in failing to waive the penalties, or a declaration that the penalties should not have been assessed in the face of the valid voluntary disclosure". See Minister of National Revenue v Sifto Canada Corp, 2014 FCA 140 at para 25 [Sifto].

${ }^{280}$ Karia v Canada (MNR), 2005 FC 639 [Karia]. Karia was followed in Wong v Canada (National Revenue), 2007 FC 628). The decision was cited in 5 decisions, all FC decision. None said that the estoppel on the basis of the IC was wrong in law or called it into question.

${ }^{281}$ Karia, supra note 218 at para 7.

282 Ibid. at para 9.

${ }^{283}$ For example see Brown v Canada (Customs and Revenue Agency), 2005 FC 1639, at para 27, where the court did not discuss estoppel and where it seems to not have been argued, the FC said that Information Circulars "cannot exclude all other valid and relevant reasons for which the Minister might exercise his discretionary authority or refuse to do so".

${ }^{284}$ See Telfer $v$ Canada (Canada Revenue Agency), 2008 FC 218, at para 13, citing to Jim's Pizza (1980) Ltd. v. Canada (Revenue Agency), 2007 FC 782. Decision overturned on appeal, 2009 FCA 23, on the basis that the decision was not unreasonable.

${ }^{285}$ Ludmer v Canada, [1995] 2 FC 3 (FCA), citing Vaillancourt v. Deputy M.N.R., [1991] 3 F.C. 663 (C.A.), where at page 674 the FCA stated:

I note that the courts are having increasing recourse to such Bulletins and they appear quite willing to see an ambiguity in the statute as a reason for using them when the interpretation given in a Bulletin squarely contradicts the interpretation suggested by the Department in a given case or allows the interpretation put forward by the taxpayer. When a taxpayer engages in business activity in response to an expressed inducement by the Government and the legality of that activity is confirmed in an Interpretation Bulletin, it is only fair to seek the meaning of the legislation in question in that bulletin also.

${ }^{286}$ Canadian Occidental U.S. Petroleum Corp. v. Canada, [2001] T.C.J. No. 112(QL) at para 30.
} 


\section{Brining it Together}

Solving tax law problems and conducting tax law research is a systematic process aimed at reaching a conclusion about a tax problem. A tax problem will be rooted in particular facts and circumstances, the solution will aim to achieve particular goals, and the path to the solution will involve presenting information to different persons in different forums. Knowing what the relevant and significant facts are, what the particular goals are, and whom you will need to convince so as to solve the problem are pre-requisites to engaging in legal research. The facts will determine the legal issues that must be addressed and explored in the research, the legal issues will determine what facts must be established, the desired outcome will determine what sources of legal information and which facts are highlighted, and the audience will determine how the results of the research are presented.

This is a cyclical process throughout the research exercise. Just as the researcher needs to re-establish what constitute relevant facts throughout the research process, the researcher must revisit the identification of legal issues. As new facts become arise or old facts become relevant the change in the factual matrix may give rise to new legal issues. Also, the exploration of legal issues may give rise to additional or secondary issues that must be examined. After the researcher has formulated clear statements of preliminary fact (and assumptions, if necessary), clear statements of the initial legal issues, a clear statement as to the purpose of the research, and identified the target audience, $\mathrm{s} / \mathrm{he}$ is ready to begin the legal research process.

Legal research, particularly in an area where the researcher is not an expert, should start with number of good secondary sources that deal with the particular and general area of law identified by the facts and posited as issues. Good secondary sources will provide the researcher with an overview of the law, references to other secondary sources (including commercial and government publications), references to related provisions in the ITA or related provisions in other statutes, and reference to leading cases. The next step involves reading the text of relevant legislation, breaking the provisions down into operating components, and culling the list of operating components down to those relevant in a particular case. In order to understand particular provisions, the researcher will have to refer to cases that interpret those provisions, or particular words or phrases used in those provisions. These cases may either be tax cases or nontax cases. After the researcher has formed an understanding of the statutory provisions as interpreted by cases, s/he must apply the law to the particular facts of the client and form an opinion as to the likely answer to the legal issues raised by those facts.

In coming to a conclusion, it is important to be aware of the limitations of any particular research and opinion. The researcher's conclusions must identify and analyze the differences between important case facts and the client's facts, assumptions of fact made, missing or unclear facts, changes or proposed changes in the law, uncertainty created by differences between the to CRA's position and the interpretation/opinion of the researcher, trends in court decisions, and other relevant matters that introduce uncertainty. Finally, in forming an opinion or giving advice, the tax researcher should remain cognizant of the burden of proof in tax cases. ${ }^{287}$ It is the

\footnotetext{
${ }^{287}$ A brief summary of the burden of proof in tax cases was provided by the TCC in Kosma-Kare Canada Inc $v$ The Queen, 2014 TCC 13, where the court made this statement at paragraph 48:
}

[The taxpayer/appellant] must put forward a prima facie case showing the inaccuracy of the assumptions relied on by the Minister when making the assessment. Such a case is supported by 
taxpayer who usually bears the burden of demolishing the assumptions of fact made by the Minister. ${ }^{288}$ The assumptions of fact made by the CRA are presumed to be correct because it is the taxpayer who is in the best position to know and establish the facts. ${ }^{289}$ This evidentiary burden on the taxpayer makes establishing the facts and understanding whether and how to prove those facts, very important. ${ }^{290}$

evidence which creates such a degree of probability in its favour that it must be accepted if believed by the Court, unless it is rebutted or the contrary is proved (Stewart v. Canada, [2000] T.C.J. No. 53 (QL). If the appellant makes such a prima facie case, the Minister must then refute that prima facie case and prove the assumptions he relied upon (Hickman Motors Ltd. v. Canada, [1997] 2 S.C.R. 336). However, the initial burden of proof put on the taxpayer cannot be lightly, capriciously or casually shifted, since the taxpayer has information within his reach and under his control (Orly Automobiles Inc. v. Canada, 2005 FCA 425, [2005] G.S.T.C. 200).

${ }^{288}$ Johnson $v$ MNR, [1948] CTC 195, 3 DTC 1182 (SCC). This burden is an extension of the statutory presumption in ITA subsection 152(8) that an assessment is deemed to be valid.

Note that the Minister bears the burden of proof on the imposition of penalties. See for example Dymond $v$ MNR 90 DTC 1920 (TCC).

${ }^{289}$ For an analysis of the onus on the taxpayer see Kroft and Douglas, "Onus and Standard of Proof in Canadian Tax Litigation: An Update" (2012) in Tax Dispute Resolution, Compliance and Administration Conference Report (Canadian Tax Foundation: Toronto, ON, 2013).

${ }^{290}$ In MNR v Pillsbury Holdings Ltd, 64 DTC 5158 (Ex Ct), the court identified the three ways in which a taxpayer can discharge this burden:

- By challenging the Minister's allegation that s/he did assume certain facts;

- By assuming the onus of showing that one or more of the assumptions is wrong; or

- By contending that, even if the assumptions made are justified, the assumptions do not by themselves support the assessment made. 


\section{Appendix 1 - Functional classification of the ITA}

\begin{tabular}{|c|c|}
\hline Function & Sections \\
\hline Liability to tax and Computing Income & $2-4$ \\
\hline Employment Income & $5-8$ \\
\hline Business and Property Income & $9-37$ \\
\hline Capital Gains & $38-55$ \\
\hline Other Sources of Income & $56-59.1$ \\
\hline Deductions in Computing Income & $60-66.8$ \\
\hline General Rules for Computing Income & $67-69$ \\
\hline Death, Family transfers, Income Splitting & $70-75.2$ \\
\hline Debts & $76-80.5$ \\
\hline Amounts not Included in Income & 81 \\
\hline Corporate Income & $82-89$ \\
\hline Shareholders of Non-resident Corporations & $90-95$ \\
\hline Partnership Income & $96-103$ \\
\hline Trust Income & $104-108$ \\
\hline Computation of Taxable Income rules & $109-114.2$ \\
\hline Income earned by Non-Residents & $115-116 ; 212-218.1$ \\
\hline Computation rules for Individuals & $117-122.71$ \\
\hline Computation Rules for Corporations & $123-125.5$ \\
\hline Computation Rules for all Taxpayers & $126-127.41$ \\
\hline Alternate Minimum Tax & $127.5-127.55$ \\
\hline Bankruptcies & 128 \\
\hline Changes in Residence & $128.1-128.3$ \\
\hline Private Corporations & 129 \\
\hline Investment Corporations & 130 \\
\hline
\end{tabular}




\begin{tabular}{|c|c|}
\hline Mortgage Investment Corporations & 130.1 \\
\hline Mutual Fund Corporations & 131 \\
\hline Mutual Fund Trusts & $132-132.2$ \\
\hline Non-Resident Owned Investment Corporations & $133-134.1$ \\
\hline Patronage Dividends & 135 \\
\hline Agricultural Co-operatives & 135.1 \\
\hline Cooperative Corporations & 136 \\
\hline Credit Unions, Savings and Credit Unions, and Deposit Insurance Corporations & $137-137.2$ \\
\hline Insurance Corporations & $138-141.1$ \\
\hline Financial Institutions & $\begin{array}{l}142.2-142.7 ; 190- \\
190.2\end{array}$ \\
\hline Communal Organizations & $143-143.1$ \\
\hline Tax Sheltered Investments & 143.2 \\
\hline Employees Plans & $144-145$ \\
\hline Registered Retirement Savings Plans & $146-146.02$ \\
\hline Registered Education Savings Plans & $\begin{array}{l}146.1-146.2 ; 204.9- \\
204.94\end{array}$ \\
\hline Registered Retirement Income Funds & $146.3 ; 204.1-204.3$ \\
\hline Registered Disability Savings Plans & $146.4 ; 205-207$ \\
\hline Deferred Profit Sharing Plans & $147 ; 198-204$ \\
\hline Registered Pension Plans & $147.1-148$ \\
\hline Eligible Funeral Arrangements & 148.1 \\
\hline Miscellaneous Exemptions & 149 \\
\hline Charities & $\begin{array}{l}149.1-149.2 ; 187.7- \\
189\end{array}$ \\
\hline Tax Returns & $150-151$ \\
\hline $\begin{array}{l}\text { Assessments, Payment of tax, Interest, Penalties, Third Party Misrepresentations, } \\
\text { Refunds, Objections, etc. }\end{array}$ & $152-168$ \\
\hline
\end{tabular}




\begin{tabular}{|l|l|}
\hline Appeals to TCC or FCA & $169-180$ \\
\hline Refundable Tax Credits & $192-195$ \\
\hline Taxable Dividends Received by Private Corporations & $186-187$ \\
\hline Tax Free Savings Accounts & $207.01-207.07$ \\
\hline Additional Tax on Non-resident Corporations & $219-219.3$ \\
\hline Administration and Collection & $220-244$ \\
\hline GAAR & $245-246$ \\
\hline Transfer Pricing & 247 \\
\hline Definitions & $248-249$ \\
\hline Interpretation Rules & $250-262$ \\
\hline
\end{tabular}

